\title{
28 Research Suare \\ T Cell Reactivity to Regulatory Factor X4 in Type 1 Narcolepsy
}

\section{Guo Luo}

Stanford University

\section{Selina Yogeshwar}

Stanford University

\section{Ling Lin}

Stanford University

Emmanuel Mignot ( $\nabla$ mignot@stanford.edu )

Stanford University

\section{Research Article}

Keywords: narcolepsy, RFX4, DQ0602, tetramer, TCR

Posted Date: February 1st, 2021

DOl: https://doi.org/10.21203/rs.3.rs-154017/v1

License: (c) (1) This work is licensed under a Creative Commons Attribution 4.0 International License. Read Full License

Version of Record: A version of this preprint was published at Scientific Reports on April 9th, 2021. See the published version at https://doi.org/10.1038/s41598-021-87481-8. 
2 T cell reactivity to Regulatory Factor X4 in Type 1 Narcolepsy ${ }^{1}$

3

4

5 Guo Luo ${ }^{1}$, Selina Yogeshwar ${ }^{1,2}$, Ling Lin ${ }^{1}$, Emmanuel Jean-Marie Mignot ${ }^{1 *}$

6

$7 \quad 1$ Stanford University Center for Sleep Sciences, Department of Psychiatry and Behavioral

8 Sciences, Stanford University School of Medicine, Palo Alto, California, United States of America

$9{ }^{2}$ Division of Biosciences, Department of Cell and Developmental Biology, University College

10 London, Gower Street, London WC1E 6BT, UK

11

12

13

14

15

16

17

18

19 Running Title: RFX4 involvement in narcolepsy

20

$21{ }^{*}$ Corresponding author

22 E-mail: mignot@ stanford.edu, (650) 725-6517 (tel), (650) 721-3448 (fax)

1 There is no funding source or conflict of interests for this research. 


\section{Abstract}

26 Type 1 narcolepsy is strongly (98\%) associated with human leukocyte antigen (HLA) class II

27 DQA1*01:02/DQB1*06:02 (DQ0602) and highly associated with T cell receptor (TCR) alpha

28 locus polymorphism as well as other immune regulatory loci. Increased incidence of narcolepsy

29 was detected following the $2009 \mathrm{H} 1 \mathrm{~N} 1$ pandemic and linked to Pandemrix ${ }^{\circledR}$ vaccination, strongly

30 supporting that narcolepsy is an autoimmune disorder. Although recent results suggest CD4+ T

31 cell reactivity to neuropeptide hypocretin/orexin and cross-reactive flu peptide is involved,

32 identification of other autoantigens has remained elusive. Here we study whether autoimmunity

33 directed against Regulatory Factor X4 (RFX4), a protein co-localized with hypocretin, is involved

34 in some cases. Studying human serum, we found that autoantibodies against RFX4 were rare.

35 Using RFX4 peptides bound to DQ0602 tetramers, antigen RFX4-86, -95, and -60 specific human

36 CD4+ T cells were detected in 4/10 patients and 2 unaffected siblings but not in others. Following

37 culture with each cognate peptide, enriched autoreactive TCR $\alpha \beta$ clones were isolated by single-

38 cell sorting and TCR sequenced. Homologous clones bearing TRBV4-2 and recognizing RFX4-

3986 in patients and one twin control of patient were identified. These results suggest the involvement

40 of RFX4 CD4+ T cell autoreactivity in some cases of narcolepsy.

43 Keywords: narcolepsy, RFX4, DQ0602, tetramer, TCR 


\section{Introduction}

Type 1 Narcolepsy (T1N) is a disabling neurological disorder that affects 1/2,000 individuals. It is characterized by excessive daytime sleepiness, disturbed nocturnal sleep, sleep paralysis,

51 hypnagogic hallucinations and sudden episodes of bi-lateral losses of muscle tone, triggered by

52 emotions (cataplexy) (1). The condition is caused by the loss of (>90\%) orexin/hypocretin

53 (HCRT)- producing neurons $(2,3)$ and is highly $(98 \%)$ associated with human leukocyte antigen

54 (HLA) class II haplotype DQA1*01:02/DQB1*06:02 (DQ0602) (4-11). Furthermore, this disorder

55 is also strongly associated with T cell receptor (TCR) alpha polymorphism and other immune 56 response genes, including cathepsin $\mathrm{H}(\mathrm{CTSH})$ and tumor necrosis factor (ligand) superfamily

57 member 4 (TNFSF4) $(4,12,13)$. An increased incidence of narcolepsy was detected, especially in 58 children in Finland, Sweden, Europe and China, following the 2009-2010 influenza A H1N1

59 pandemic and associated vaccination campaign with Pandemrix ${ }^{\circledR}$ (14-24). It was also reported that

60 cases of T1N were triggered by other environmental factors, including Streptococcus infection,

61 which has previously been associated with a number of autoimmune diseases (15, 25-30). Taken

62 together, this data strongly suggests that $\mathrm{T} 1 \mathrm{~N}$ is an autoimmune disorder.

64 So far, no consistent autoantibodies have been found in T1N in spite of large efforts. One of the 65 most promising autoantigens first identified was TRIB2 (31), a protein initially thought to be 66 enriched in HCRT cells. It was shown by three different studies, including one by our group, that

67 TRIB2 autoantibody levels are elevated in recent onset narcolepsy cases (32). However, later 68 efforts failed to consistently confirm this finding $(33,34)$. 
70 Similarly, numerous efforts were exerted to screen for autoantibodies against HCRT, HCRT

71 receptor 1 (HCRTR1) and HCRTR2 in T1N patients and healthy controls (35-37). Although

72 Ahmed et al. (2015) report anti-HCRTR2 autoantibodies in the majority of post-Pandemrix ${ }^{\circledR}$

73 narcolepsy patients tested (17 of 20 sera) (38), others utilizing a similar protocol have reported

74 conflicting results in both sporadic narcolepsy patients (5 of 181, 3 of 61 sera) and post-

75 Pandemrix $^{\circledR}$ narcolepsy patients (0 of 40 sera) (37). Results suggesting association of anti-

76 streptolysin O (ASO) and anti-DNAse B (ADB) antibodies with recent narcolepsy onset could not

77 be replicated either in China $(25,27,39)$. Notably, Deloumeau and colleagues (2010) identified

78 higher level of IgG complexed with HCRT1 in T1N patients compared to controls, whereby overall

79 serum levels of IgG did not differ between the two groups (40, 41). Recent techniques used have

80 included radioligand-binding (35), cell-based enzyme-linked immunosorbent (ELISA) (38) and

81 flow cytometry-based assays $(37,42,43)$, all with negative results. While the general consensus

82 is now that a $\mathrm{T}$ cell mediated response is likely the primary mechanism underlying $\mathrm{T} 1 \mathrm{~N}$, it yet

83 remains an enigma whether this cascade may also generate a humoral response with the presence

84 of any antibodies specifically and reliably associated with T1N remaining contentious.

86 In contrast to the findings concerning antibody-mediated immunity, adaptive cell-mediated

87 immunity has been increasingly and robustly implicated in the pathophysiology of narcolepsy (44,

88 45), a result that fits well with genetic data indicating association with HLA and TCR loci. Thanks

89 to HLA class I and II multimers and fluorescence-activated cell sorting (FACS)-based single cell

90 sorting and sequencing technologies, investigation of cellular immune responses to infectious

91 agents and autoantigens in autoimmune diseases is now possible in more details $(46,47)$.

92 Specifically, tetramer HLA-targeted $\mathrm{T}$ cells facilitates identification of antigen specific TCR-

93 groups within highly diverse TCR repertoires $(48,49)$, which are stochastically generated by 
$94 \mathrm{~V}(\mathrm{D}) \mathrm{J}$ recombination, a process rearranging germline TCR loci in each T cell $(50,51)$. Using this

95 technology, there is increasing evidence of CD4 autoreactivity directed against HCRT itself may 96 indeed be a major autoreactive process in human narcolepsy $(46,52)$.

97

98 In this study, we hypothesize that regulatory factor X4 (RFX4) might be another important CD4+ 99 T cell autoantigen in T1N, due to its high enrichment in HCRT cells $(34,53,54)$. RFX members 100 share a highly-conserved deoxyribonucleic acid (DNA)-binding domain (55) and regulate 101 expression of their target genes, including major histocompatibility complex class II (MHCII) and 102 interleukin-5 receptor $\alpha$ chain (IL-5R $\alpha$ ) (56-63). Six isoforms of RFX4 have been identified (64). 103 While RFX4 variant 1 (RFX4_v1), RFX4_v2 and RFX4_v4 are specifically expressed in testis 104 (61, 65), expressions of both RFX4_v5 and RFX4_v6 is observed exclusively in gliomas (65). 105 RFX4_v3 is specifically expressed in the brain and is crucial for brain morphogenesis, being 106 involved in many aspects of brain development and disease (64-69). Of notable interest is the fact 107 RFX4_v3 is expressed in the suprachiasmatic nucleus (SCN), the mammalian pacemaker 108 responsible for generating a 24-h-circadian rhythm (70-72). It can also be induced by light 109 exposure in a subjective night-specific manner, a typical characteristic of several other core SCN 110 circadian genes (73), suggesting a role in circadian regulation. This hypothesis is further supported 111 by findings of Glaser and colleagues (2005), who identified RFX4_v3 as a potential risk factor for 112 Bipolar disorder (BPD) (74), a condition frequently featuring severe circadian instability (75-77).

113 Intriguingly, RFX4 is highly enriched in-, and significantly specific to HCRT neurons, according 114 to the results of translating ribosome affinity purification (TRAP) $(34,53,54)$. Nevertheless, little 115 is known about the regulatory network of RFX4 and the role it exerts on HCRT neurons. Taken 116 together, the implication of RFX4 in circadian regulation, its hypocretin neuron specific expression 
117 and the effect of related members on MHC class II genes, renders this protein an interesting

118 candidate for investigation as an autoantigen in $\mathrm{T} 1 \mathrm{~N}$. Of additional interest is the fact CD8+

119 directed T cell activity against this antigen has also been shown in a recent study of narcolepsy

120 patients (45).

122 To further explore the hypothesis that immune reactivity directed toward RFX4 is relevant to 123 narcolepsy pathophysiology and hypocretin cell loss, we searched for autoantibodies directed 124 against RFX4_v1/v3/v4 in 86 T1N patients and 88 controls using high throughput flow cytometry125 based (FACS) staining assays and explored T cell reactivity to RFX4 peptides bound to DQ0602.

126 FACS positive samples for autoantibodies were confirmed using cell-based immunostaining and

127 western blotting. While no autoantibodies were found, T cell binding DQ0602-RFX4 tetramers

128 were found in four patients and two sibling controls of cases. The corresponding RFX4 antigen,

129 DQ0602 restricted specific CD4+ T cells were next single-cell sorted for TCR sequencing and 130 unique clone enrichment and preferential v-gene segments in TCR repertoires observed. Finally, 131 activation of enriched TCR clones by RFX4 peptides was studied in vitro, showing functional 132 effects. Altogether, our results provide evidence for the involvement of RFX4 in the 133 pathophysiology of at least a few T1N cases. 


\section{Materials and Methods}

\section{Ethics Statement}

142 This study has been reviewed and approved by the Stanford University Institutional Review Board

143 (Protocol \# 14325, Registration \# 5136). Informed consent was obtained from each participant.

144 We confirm that all methods were carried out in accordance with relevant guidelines and 145 regulations.

\section{Participants}

148 For anti-RFX4 autoantibody detection, two groups of matched T1N patients and controls were 149 created. One group consists of 39 post-Pandemrix ${ }^{\circledR} \mathrm{T} 1 \mathrm{~N}(\mathrm{PP}-\mathrm{N})$ cases (mean age \pm standard error 150 of the mean (SEM): $14.9 \pm 1.26,30 \%$ male) and 18 post-Pandemrix ${ }^{\circledR}$ controls (PP-C) (mean age $151 \pm$ SEM: $13.17 \pm 0.97,39 \%$ male), the other group consists of 47 recent early onset T1N (EO-N) 152 cases (mean age \pm SEM: $12.95 \pm 1.43,58 \%$ male) and 70 other controls $(\mathrm{O}-\mathrm{C})$ (mean age \pm SEM: $15318.85 \pm 1.31,46 \%$ male) (Dataset 1). All patients meet international classification of sleep 154 disorders 3 (ICSD3) criteria (http://www.aasmnet.org/store/product.aspx?pid = 849) for type 1 155 T1N. All are DQ0602 positive with one exception, a patient known to have low cerebrospinal fluid 156 (CSF) hypocretin-1 levels. For T cell reactivity examination, 3 early onset T1N patients, 7 post157 Pandemrix ${ }^{\circledR}$ T1N patients, 5 post-Pandemrix ${ }^{\circledR}$ controls, and 1 other control were tested and detailed 158 information was summarized in Dataset 2. All 16 subjects are DQ0602 positive. Flow cytometry 159 dot plots of 10 out of 16 subjects were also shown in S11 in Luo et al. (2018) (46). 
$161 \quad$ Vaccine

162 Pandemrix $^{\circledR}$ (A/California/7/2009 (H1N1) NYMC X-179A monovalent bulk (inactivated, sterile)) 163 (Batch\# AFLSFDA280) was used throughout the study. It was manufactured with HA content at $164139 \mu \mathrm{g} / \mathrm{ml}$ (determined with single radial diffusion (SRD)) by GlaxoSmithKline (GSK) Dresden 165 in January 2010. This batch has been used during the 2009-2010 vaccination campaign in Europe.

166 Summary of Pandemrix ${ }^{\circledR}$ characteristics can be found in the European Medicines Agency library 167 (http://www.ema.europa.eu/docs/en_GB/document_library/Other/2010/05/WC500091295.pdf).

169 RFX4 constructs

170 Original clones of RFX4_v1 (Cat\# RG205481, OriGene), RFX4_v3 (Cat\# RG223334, OriGene),

171 RFX4_v4 (Cat\# RG233113, OriGene) and green fluorescent protein (GFP) expression vector 172 pCMV6-AC-GFP (Cat\# PS100010, OriGene) were purchased from OriGene. These were 173 transformed to TOP10 competent cells (Cat\# C404003, Invitrogen) and plasmids purified from 174 bacterial culture using EndoFree ${ }^{\circledR}$ plasmid maxi kit (Cat\# 12362, QIAGEN).

175

176 Anti-RFX4 autoantibody detection with flow cytometry

177 Detailed protocol and quantitation analysis methods have been described previously (42, 43).

178 Briefly, human embryonic kidney (HEK) 293T cells (ATCC ${ }^{\circledR}$ CRL-3216 ${ }^{\circledR}$ ) were cultured in 179 Dulbecco's modified Eagle's medium (DMEM) (Cat\# ATCC ${ }^{\circledR}$ 30-2002, ATCC), supplemented 180 with $10 \%$ fetal bovine serum (FBS) (Cat\# 26140079, Gibco) and 1\% penicillin-streptomycin 181 (Pen/Strep) (Cat\# 15140-122, Gibco) in a 75 $\mathrm{cm}^{2}$ tissue culture flask (REF\# 658175, CELLSTAR) 182 at $37^{\circ} \mathrm{C}, 5 \% \mathrm{CO}_{2}$, and transfected with RFX4_v1, RFX4_v3, RFX4_v4 or pCMV6-AC-GFP using 
183 the Lipofectamine ${ }^{\circledR} 3000$ reagent (Cat\# L3000015, Invitrogen) in Opti-MEM ${ }^{\circledR}$ I reduced serum

184 medium (REF\# 31985070, Gibco). After 24 hours, cells were harvested and stained with Zombie

$185 \mathrm{NIR}^{\circledR}$ (Cat\# 423106, BioLegend), followed by fixation and permeabilization with fix/perm buffer

186 set (Cat\# 421403, BioLegend) according to the manufacturer's instructions. Validation and

187 sensitivity were detected using two positive antibodies: mouse anti-RFX4 antibody (Cat\#

188 H00005992-B01P, Abnova) (Supplemental Fig. 1) and rabbit anti-RFX4 antibody (Cat\# NBP2-

189 48967, Novus) (Supplemental Fig. 2), followed by staining with R-phycoerythrin (PE) anti-mouse

190 immunoglobulin (Ig)G (REF\# 12-4010-82, eBioscience) and PE anti-rabbit IgG (REF\# 12-4739-

191 81, eBioscience) (1:100), respectively. Cells were incubated with human serum (1:20) for 1 hour

192 at $4^{\circ} \mathrm{C}$, followed by staining with PE anti-human $\operatorname{Ig} \lambda$ antibody (REF\# 12-9990-42, eBioscience)

193 (1:100) and PE anti-human Igא antibody (REF\# 12-9970-42, eBioscience) (1:100). Nonspecific

194 binding was removed by washing with $0.05 \%$ Tween-20 in PBS. Cells were run on BD LSRII and

195 data were analyzed with Flow Jo (version 10.0.8).

197 Quantitation analysis methods were modified as follows: for each sample, mean fluorescence 198 intensities (MFI) of PE channel (MFI ${ }^{\mathrm{PE}}$ ) within live GFP positive HEK293T cells (HEK293T ${ }^{\mathrm{GFP}+}$ ) 199 and GFP negative HEK293T cells (HEK293T ${ }^{\mathrm{GFP}-}$ ) were calculated, then $\Delta \mathrm{MFI}^{\mathrm{PE}}$ was determined 200 by subtracting $\mathrm{MFI}^{\mathrm{PE}}$ of HEK293T ${ }^{\mathrm{GFP}-}$ from $\mathrm{MFI}^{\mathrm{PE}}$ of HEK293T ${ }^{\mathrm{GFP}+}$. Cut-off value of $\Delta \mathrm{MFI}^{\mathrm{PE}}$ 201 was determined as the mean of $\Delta \mathrm{MFI}^{\mathrm{PE}}+3 \times$ standard deviation (SD) of control samples (35).

203 Cell-based assay (CBA) for autoantibody detection under microscope

204 A protocol described previously (36) was used. Briefly, HEK293T cells were cultured and 205 transfected (as described above) on glass coverslip (REF\# 354085, Corning) in a 12-well plate 
206 (REF\# 353043, Corning). After 24 hours, cells were fixed and permeabilized, and then incubated

207 with human serum (1:20) or rabbit anti-RFX4 antibody (1:500) for 2 hours at room temperature 208 (RT) in the dark, followed by Alexa Fluor ${ }^{\circledR}$ (AF) 555-conjugated anti-human IgG antibody (Cat\# 209 A-21433, ThermoFisher) (1:500) or AF555-conjugated anti-rabbit IgG antibody (Cat\# A-21428, 210 ThermoFisher) (1:500), respectively. All antibodies or sera were diluted in perm buffer and cells 211 were washed twice with perm buffer after each incubation. Images were taken by EVOS ${ }^{\circledR}$ FL 212 imaging system (Cat\# AMF4300, ThermoFisher). Images were analyzed using ImageJ2.0.0 image 213 processing software. An area in the region of interest was selected and all DAPI+GFP+ and 214 DAPI+GFP+AF555+ cells were counted using the cell counter plugin in ImageJ.

\section{Immunoprecipitation (IP)}

217 HEK293T cells (equal aliquot) were cultured and transfected in $75 \mathrm{~cm}^{2}$ flasks as described above. 218 After 24 hours, cells were harvested, washed with cold phosphate buffered saline (PBS) (Cat\# 219 10010-049, Gibco) and lysed in RIPA buffer (Cat\# 89900, ThermoFisher) supplemented with 220 complete protease inhibitor (REF\# 11873580001, Roche) on ice for 15 minutes. Debris was 221 removed by centrifugation at 12,000 rpm for 15 minutes. Supernatant was incubated with anti222 tGFP-conjugated agarose beads (Cat\# TA183081, OriGene) overnight at $4^{\circ} \mathrm{C}$ by end-to-end 223 rotation. These beads were washed 3 times and boiled at $95^{\circ} \mathrm{C}$ for 10 minutes after adding $50 \mu 1$ 224 of $4 \times$ Laemmli buffer (Cat\# 1610747, Bio-Rad). Supernatant was loaded to a precast gel (Cat\# 225 4561093, Bio-Rad) for western blotting. 


\section{Western blotting}

228 For western blotting protocol, see https://www.bio-

$229 \mathrm{rad.com/webroot/web/pdf/lsr/literature/Bulletin \_ 2895.pdf.} \mathrm{Briefly,} \mathrm{proteins} \mathrm{were} \mathrm{transferred} \mathrm{from}$ 230 gel to a PVDF membrane (Cat\# IPVH00010, EMD Millipore) and then incubated with primary

231 anti-RFX4 antibody (Cat\# H00005992-B01P, Abnova) (1:2,000) or human serum (1:50) $(200 \mu 1$

232 in $10 \mathrm{ml}$ of blocking buffer) for 2 hours at RT, followed by secondary peroxidase-conjugated anti-

233 mouse IgG antibody (Code\# 715-035-150, Jackson ImmnuoResearch) (1:5,000) or anti-human Ig $\lambda$

234 (NBP1-73715, Novus) (1:5,000) and anti-human Igא (NB7466, Novus) (1:5,000), respectively.

235 Non-specific binding was removed through extensive washing of $3 * 10$ minutes with $0.05 \%$

236 Tween-20 in PBS. Chemiluminescent substrate (Prod\# 32106, ThermoFisher) was applied to the

237 blot and film (Cat\# 28906838, GE Healthcare) was developed with a tablet processor (Item\# SRX-

238 101A, Konica).

$240 \quad$ RFX4 peptide library

241 An overlapping 15-mer peptide (11-amino acid overlap) library covered 6 RFX4 variants. Each

242 peptide was synthesized with $>90 \%$ purity at GenScript and dissolved in dimethyl sulfoxide

243 (DMSO) at a stock concentration of $5 \mathrm{mM}$.

\section{Tetramer DQ0602-peptide staining and Single cell TCR sequencing (TCRseq)}

246 The full protocol was described previously $(78,79)$. In brief, biotinylated DQ0602 was loaded

247 with peptide at $\mathrm{pH} 5.2$ and incubated with PE-conjugated streptavidin. Peripheral blood

248 mononuclear cells (PBMCs) were stained with concentrated and purified tetramer DQ0602249 peptide and antibody cocktail, followed by Fluorescence-activated cell sorting (FACS) 
250 (Supplemental Fig. 4). Tetramer DQ0602-peptide positive CD4+ T cells were single-cell sorted 251 into 96-well plates for single cell TCR sequencing.

\section{Luciferase activity}

254 TCR $\alpha \beta$ chains tagged with GFP were cloned to N103 vector (a gift from Dr. Mark Davis) by IDT 255 (Integrated DNA Technologies, Inc.). Jurkat 76 (J76)-NFATRE-luc cells (a gift from Dr. Mark 256 Davis) were transfected with TCR using the Lipofectamine ${ }^{\circledR} 3000$ reagent (Cat\# L3000015, 257 Invitrogen). TCR positive cells were sorted using anti-human TCR $\alpha / \beta$ antibody (Cat\# 306702, 258 BioLegend). In $200 \mu$ l of complete RPMI medium (RPMI (Cat\# 61870-036, Gibco) supplemented 259 with $10 \%$ FBS and 1\% Pen/Strep), 0.1 million of J76-TCR cells were co-cultured with 0.1 million 260 of RM3-DQ0602 (80) cells at the presence of $10 \mu \mathrm{M}$ of pHA273-287, NP17-31, HCRT54-66-NH2, 261 HCRT $86-97-\mathrm{NH} 2$, or RFX4-43, or $5 \mu \mathrm{M}$ of RFX4-86, RFX4-95, or RFX4-60 or 0.2 $\mu 1$ DMSO for 8 262 hours. Luciferase activity was detected with Nano-Glo Luciferase Assay Kit (Cat\# N1130, 263 Promega).

\section{Statistical analysis}

266 For anti-RFX4 autoantibody analysis and luminescence of J76-TCR, values were expressed as 267 mean \pm SD and mean \pm Standard Error of the Mean (SEM), respectively. Statistical comparisons 268 were calculated with two-tailed $t$-tests. Data were plotted using GraphPad Prism 5 and R. P-value $269<0.05$ was considered statistically significant. 


\section{Results}

275 Autoantibodies against RFX4 are absent or very rare in cases and controls

276 To test for the presence of autoantibodies directed against RFX4 in T1N cases, RFX4_v1,

277 RFX4_v3 and RFX4_v4 tagged with green fluorescent protein (GFP) were expressed in human 278 embryonic kidney (HEK) 293T cells. Mean fluorescence intensities (MFI) of R-phycoerythrin

279 (PE) were recorded using quantitative flow cytometry-based assay after staining HEK293T cells 280 with sera of 39 post-Pandemrix ${ }^{\circledR}$ T1N (PP-N) cases, 18 post-Pandemrix ${ }^{\circledR}$ controls (PP-C), 47 281 recent early onset T1N (EO-N) cases, and 70 other controls (O-C), and secondary PE-conjugated 282 anti-human immunoglobulin (Ig). Comparing $\triangle \mathrm{MFI}^{\mathrm{PE}}$ determined by subtracting $\mathrm{MFI}^{\mathrm{PE}}$ of 283 HEK293T ${ }^{\text {GFP- }}$ from MFIPE of HEK293T ${ }^{\mathrm{GFP}+}$, no significant difference was observed between 284 patients and controls for either v1, v3, or v4, however, anti-RFX4_v3 autoantibody level in PP-N 285 cases were significantly higher compared to patients without vaccination and vaccinated controls 286 (p-value $=0.018$ and 0.006 , respectively) (Fig. 1A). Out of 174 subjects, autoantibody levels of 287 anti-RFX4_v1, v3 and v4 above cut-off were detected in one (O-C), three (2 PP-N and 1 O-C) and 288 two (1 PP-N and 1 O-C) subjects, respectively (Fig. 1A and Dataset 3), thus suggesting anti-RFX4 289 autoantibodies are rare. Furthermore, two PP-N patients and one O-C showed positive correlations 290 between PE and GFP signals for RFX4_v3, but not for v1 or v4 (Fig. 1B), which was confirmed 291 by cell-based immunostaining assay (CBA) (Fig. 1C) and using western blotting (Fig. 1D), 292 therefore validating results attained using high sensitive flow cytometry-based assay. Taken 293 together, these findings show that autoantibodies against RFX4 are very rare, and are unlikely to 294 mediate pathology in T1N, as already suggested by previous studies (35-37). 


\section{Detection of RFX4 antigen specific CD4+ T cells}

298 To detect antigen-specific CD4+ T cells, peripheral blood mononuclear cells (PBMCs) of 3 EO299 N, 7 PP-N, 5 PP-C and 1 O-C were cultured with Pandemrix ${ }^{\circledR}$ or a single RFX4 peptide and then 300 stained with tetramer DQ0602, loaded by 32 strong and 6 weak RFX4 peptides (Table I). Sporadic 301 pattern of Pandemrix ${ }^{\circledR}$ (Supplemental Fig. 3) stimulation suggested no cross reactivity between 302 Pandemrix ${ }^{\circledR}$ and RFX4. Notably, stimulation with the three different peptides, RFX4-60, -86 and $303-95$, resulted in clearly separated populations of specific CD4+ T cells in four patients and two 304 sibling controls of cases (Fig. 2A), suggesting T cell response engagement with RFX4 in these 305 narcoleptic cases

307 T cell reactivity to RFX4-86 presented by DQ0602 was detected in both 2 PP-N (021 and 948) and 3082 PP-C subjects (5688 and 901) while recognition of RFX4-95 was only found in 2 PP-N patients 309 (021 and 900) (Fig. 2A). T cell reactivity to RFX4-60 was solely detected in one EO-N patient

310 (848) with a tail-like pattern (Fig. 2A). Notably, patient 021 reacted to both RFX4-86 and RFX4-

311 96, which are shared in all 6 RFX4-variants (Table I). Altogether, these findings reveal RFX4312 specific CD4+ T cells in both post-Pandemrix ${ }^{\circledR}$ and early-onset narcolepsy patients, therefore 313 suggesting involvement of RFX4 in T cell immunity of narcolepsy.

\section{RFX4 antigen specific single CD4+ $\mathbf{T}$ cell TCR sequencing}

316 In the next step, our aim was to determine the identity of RFX4-specific CD4+ T cells. Antigen 317 specific CD4+CD8- T cells of 7 positive reactions to the three peptides RFX4-86, -95, and -60 in 3186 subjects were single-cell sorted into 96-well plates for TCR $\alpha$ and $\beta$ sequencing (i.e. 7 x 96 cells 
319 in total) (Dataset 4). For each peptide-subject reaction, more than 65 out of 96 (68\%) cells were 320 recovered with pairing TCR $\alpha \beta$, except for RFX4-86/5688 (twin control of case, 40 cells, 42\%) and 321 RFX4-60/848 (PP-N, 12 cells, 13\%) (Fig. 2B, Dataset 4). One TCR $\alpha \beta$ pair in each RFX4 peptide322 subject reaction was enriched at least $43 \%$ ( $>=7$ counts) (Fig. 2B). For example, two TCR $\alpha \beta$ pairs 323 enriched in PP-N patient 021 reacted to either RFX4-86 (73\% and 22\%) or RFX4-95 (46\% and

324 38\%), while a single TCR $\alpha \beta$ pair was enriched in RFX4-86 PP-N patient 948 (79\%), RFX4-86 O325 C 5688 (58\%) and PP-C 901 (43\%), RFX4-95 PP-N 900 (89\%) and RFX4-60 PP-N 848 (58\%) 326 (Fig. 2B). Notably, RFX4-86 TRBV4-2, which is associated with T1N(13), was also enriched in 327 one patient (79\%) and one control (58\%) (Fig. 2B).

329 Next, the usage of TCR V gene segments in patients and controls was analyzed. TRBV28 (34\%) 330 and TRBV4-2 (32\%) were the two most frequently used V gene segments in patients and controls 331 respectively (Fig. 2C). Notably, TRBV4-2, which has previously been associated with T1N (13), 332 was also frequently used in patients (19\%). Contrastingly, however, frequently used TRAV genes 333 showed significantly more diversification between patients and controls (Fig. 2C).

335 Frequent usage of TRBV and TRAV/TRBV pairings was distinct between RFX4-86, -95, and -60 336 (Fig. 2C and D). In RFX4-86, TRBV4-2 (36\%) most frequently paired to TRAV2 (52 counts, 337 20\%) in patients and TRAV38-2/DV-8 (23 counts, 9\%) in controls, while for RFX4-60, TRBV14 338 (58\%) paired to TRAV29/DV5 (7 counts, 58\%) in patients (in controls, no pairing of more than 5 339 cells could be identified). In RFX4-95, TRBV28 (69\%) paired to TRAV19 (74 counts, 49\%) and 340 TRAV3 (26 counts, 17\%) in patients (Fig. 2D). Taken together, these findings show that TCR is 
341 enriched in tetramer DQ0602 positive CD4+ T cells and V gene segments are partially similar

342 between patients and controls, however, differ significantly between RFX4-86, -95 and -60.

344 TRBV4-2 is involved in RFX4 narcolepsy

345 In a last step, our aim was to probe the reactivity of specific TCRs to RFX4-86, RFX4-95 and

346 RFX4-60. Therefore, enriched TCR $\alpha \beta s$ (>= 7 clones, Table II) were expressed in Jurkat 76 (J76)-

347 NFATRE-luc cells, which lack native TCRs and subsequently co-cultured with antigen presenting

348 cells (APCs) RM3-DQ0602. Luciferase activity showed that TCR162

349 (TRBV28_CASSSSGQGGNSPLHF_TRBJ1-6/TRAV19_CALSGDVYGGSQGNLIF_TRAJ42),

350 TCR166 (TRBV2_CASSGQGSYEQYF_TRBJ2-7/TRAV9-2_CALSSLWGEKLTF_TRAJ48)

351 and TCR170 (TRBV28_CASSFSGTRTGELFF_TRBJ2-2/TRAV12-

352 2_CAVMPNDYKLSF_TRAJ20) significantly reacted to RFX4-95. Four TCRs showed reactivity

353 against RFX4-86, namely TCR163 (TRBV12-3_CASSLRGLNYGYTF_TRBJ1-

354 2/TRAV41_CAVLNRDDKIIF_TRAJ30), TCR165 (TRBV4-2_CASSQEGGKETQYF_TRBJ2-

355 5/TRAV6_CALDRGTDKLIF_TRAJ34), TCR172 (TRBV5-6_CASSLGPRTPKGQYF_TRBJ2-

356 7/TRAV39_CAVENNNDMRF_TRAJ43) and TCR173 (TRBV4-

357 2_CASSQDVRQGGYGYTF_TRBJ1-2/TRAV29/DV5_CAASDQAGTALIF_TRAJ15). Lastly, 358 TCR174 (TRBV14_CASSLQGRRGDTQYF_BJ2-

359 3/TRAV29/DV5_CAASAGAGSYQLTF_TRAJ7) was shown to react against RFX4-60 (Fig. 3).

360 As outlined earlier, TRBV4-2 is among a number of specific TCR segments of interest in the

361 context of narcolepsy, as genetic QTL locations modulating its usage are strongly associated with

362 this condition (13). Notably, two out of four (50\%) TCRs reactive against RFX4-86 (TCR165 and

363 TCR173) shared TRBV4-2, hence suggesting causality and cardinally implicating T cell reactivity 
364 against RFX4-86 via TRBV4-2 in some cases of narcolepsy. Notably, no cross-reaction between

365 RFX4 and HCRT/Pandemrix ${ }^{\circledR}$ was detected, suggesting these TCRs are RFX4 specific (Fig. 3).

366 TCR activation by RFX4 further suggests RFX4 is involved in T1N. 


\section{Discussion}

386 The autoimmune hypothesis of narcolepsy arose more than thirty years ago based on the strong 387 association of HLA-DQ0602 of the disorder, and although initially, evidence in support of this 388 hypothesis was hard to demonstrate, recent data now suggest $\mathrm{T}$ cell involvement in the destruction 389 of HCRT cells. In this work, we investigate whether RFX4, which is highly enriched in HCRT 390 cells, might be a relevant autoantigen in T1N. This was done by testing for the presence of 391 autoantibody and/or of DQ0602 restricted T cell reactivity against it.

393 Whether or not autoantibodies are involved in the pathophysiology of narcolepsy is controversial.

394 Studies of autoantibodies directed against hypocretin and hypocretin receptors in narcolepsy 395 patients have rendered mixed results (35-38). Other groups have studied reactivity to other 396 proteins expressed in HCRT cells, such as TRIB2, with similarly mixed results $(31,81)$. Our 397 results show that autoantibodies against RFX4 are rare in T1N patients, with anti-RFX4_v3 398 autoantibody-like reactivity being significantly increased solely in two patients (1\%), both 399 vaccinated with Pandemrix ${ }^{\circledR}$. None of these patients were positive for anti-HCRTR2 400 autoantibodies (37). For anti-RFX4_v1/v4 autoantibodies, $\Delta \mathrm{MFI}^{\mathrm{PE}}$ of subject(s) above cut-off

401 could not be repeated and dot plots showed no obvious correlation between PE and GFP channels 402 (Fig. 1), suggesting that anti-RFX4_v1/v4 autoantibody levels in these subjects were too low to be 403 detected. Taken together, these findings support previous data from our lab and others (34), 404 supporting that autoantibodies are unlikely to be involved in the pathophysiology of narcolepsy. 405 Further to this, our findings validate that high throughput flow cytometry-based autoantibody 406 detection assay as a method for primary autoantibody screening is reliable, and not solely for 407 surface antigens. 
409 Next, we probed the presence of antigen specific CD4+ T cells by co-culturing PBMCs from early410 onset and post-Pandemrix ${ }^{\circledR}$ T1N patients with Pandemrix ${ }^{\circledR}$ or a single RFX4 peptide. Although 411 tetramer DQ0602 positive CD4+ T cells were not clearly clustered when stimulated with

412 Pandemrix ${ }^{\circledR}$, they were observed sporadically in both patients and controls. For example, cells 413 reactive against $\mathrm{RFX} 4-36,-76$, and -172 were identified in an early-onset patient (165), PP-N 414 patient (900), and PP-C (023), respectively (Supplemental Fig. 3). The proportions of CD4+ T 415 cells recognized by tetramer pDQ0602 in CD3+ T cell populations were very small (generally 416 lower than $0.085 \%$, most $<0.05 \%$ ), except for one control (901), which also had high background 417 (peptide NC, 0.12\%) (Supplemental Fig. 3).

419 In probing for the presence of RFX4-antigen specific CD4+ T cells, we detected reactivity against 420 RFX4-60, -86 and -95 in one EO-N, three PP-N patients and two controls. We therefore sought to 421 determine the identity of these cells further and conducted single cell TCR sequencing of reactive 422 cells. Analysis of frequently used TRAV/TRBV pairings revealed that although V gene segments 423 are partially similar between patients and controls, they differ significantly between RFX4-86, -95

424 and -60 . To probe the reactivity of specific TCRs to these three peptides, we expressed enriched 425 TCR $\alpha \beta s$ in Jurkat 76 (J76)-NFATRE-luc cells co-cultured with RM3-DQ0602. Most notably, 50\% 426 of TCRs reactive against RFX4-86 shared TRBV4-2, which has been strongly implicated in 427 narcolepsy pathophysiology by our lab before though genetic analysis (13).

429 Although the autoimmune etiology of T1N was recently solidified, the exact pathophysiology 430 underlying this disorder still remains elusive. Our findings suggest that future work should be 
431 dedicated to investigating the exact role of RFX4 in T1N and how reactivity to this protein may

432 impact HCRT neuronal death. Competing binding assay and DQ0603 tetramer staining assays,

433 although laborious, were found to be feasible and reliable for screening autoantigen reactivity in

$434 \mathrm{~T} 1 \mathrm{~N}$, so that these may now be extended to the study of more antigens and patients using new

435 technologies that have higher throughput. Such additional experiments could for example use 10x

436 compatible single cell analysis with DNA barcode labelling and pooling of tetramer reactivity for

437 both strong and weak RFX4 to DQ0602. Single cell TCR sequencing and phenotyping of more

438 RFX4 specific CD4+ and CD8+ T cells could elucidate the role of RFX4 in pathophysiology of 439 narcolepsy.

441 In conclusion, we provide preliminary evidence for the involvement of RFX4 in T1N in some 442 subjects through both anti-RFX4 autoantibody detection and tetramer DQ0602-strong RFX4 443 binders staining. Most notable was the enrichment of TRBV4-2, which we have previously shown 444 to be genetically associated with T1N (13) and involved in T cell recognition of HCRT-NH2 in 445 this disorder (46), hence suggesting causality. We propose an involvement of $\mathrm{T}$ cell reactivity 446 against specific RFX4 peptides in the pathophysiology of some T1N cases. 


\section{Acknowledgement}

454 We thank Dr. K. Christopher Garcia for sharing expression constructs, Sf9 and Hi5 cell lines and 455 NIH tetramer core facility for sharing DQA1*01:02/DQB1*0602 expression constructs. We thank 456 Wenchao Sun from Stanford Biomaterials and Advanced Drug Delivery Lab for HPLC running 457 and Xuhuai Ji from Human Immune Monitoring Center at Stanford for TCR sequencing. We thank 458 Stanford FACS facility for providing analyzers and sorters and technical support.

459 


\section{Figure legends}

475 Fig. 1. Anti-RFX4 autoantibody detection. (A) Sera were screened using HEK293T cells 476 expressing GFP tagged RFX4 variants and PE-conjugated anti-human $\operatorname{Ig} \lambda / \kappa$ antibody. Analysis 477 was performed between groups of post-Pandemrix ${ }^{\circledR}$ T1N (PP-N) patients, post-Pandemrix ${ }^{\circledR}$ 478 controls (PP-C), recent early onset T1N (EO-N) patients, and other controls (O-C) for RFX4_v1, 479 RFX4_v3, and RFX4_v4. Each dot corresponds to one subject. $\triangle \mathrm{MFI}^{\mathrm{PE}}=\left(\mathrm{MFI}^{\mathrm{PE}}\right.$ of 480 HEK293T $\left.{ }^{\mathrm{GFP}+}\right)$ - (MFI ${ }^{\mathrm{PE}}$ of HEK293T $\left.{ }^{\mathrm{GFP}-}\right)$. Cut-off value of $\Delta \mathrm{MFI}^{\mathrm{PE}}$, which is denoted by dotted 481 line, was determined as the mean of $\Delta \mathrm{MFI}^{\mathrm{PE}}+3 \times$ standard deviation (SD) of control samples. 482 Subject IDs above cut-off value and statistical significance are shown. *, P < 0.05; **, P < 0.01 . It 483 was independently repeated once. (B) FACS dot plots of three subjects in anti-RFX4 autoantibody 484 detection. HEK293T cells expressing RFX4_v1, v3 and v4-GFP were incubated with human 485 serum (1:20) or positive rabbit anti-RFX4 antibody, followed by PE anti-human $\operatorname{Ig} \lambda / \kappa$ antibody 486 (1:100) or PE anti-rabbit IgG antibody (1:100), respectively. Representative dot plots of 3 subjects 487 and positive antibody (1:500) with \% of each quadrant population in live single cells are shown. $488 \mathrm{Ab}$, antibody. It was independently repeated once. (C) Anti-RFX4_v3 autoantibody detection 489 using cell-based immunostaining and observation under microscope. HEK293T cells expressing 490 GFP-tagged RFX4_v1, v3, and v4 were stained with human serum (1:20) or rabbit anti-RFX4 491 antibody (Ab) (1:500), followed by AF555-conjugated anti-human IgG antibody (1:500) or 492 AF555-conjugated anti-rabbit IgG antibody (1:500), respectively. 3 subjects with $\triangle \mathrm{MFI}^{\mathrm{PE}}$ above 493 cut-off value of RFX4_v3 were tested. Bar=200 $\mu \mathrm{m}$. It was performed once. (D) Anti-RFX4 494 autoantibody detection using western blotting. HEK293T cells expressing GFP-tagged RFX4_v1, 495 v3, v4 and vector were lysed and anti-tGFP-conjugated agarose beads were incubated with 496 supernatant for Co-IP. Positive antibody and three subjects with $\Delta \mathrm{MFI}^{\mathrm{PE}}$ above cut-off value were 
tested. RFX4_v1, RFX4_v3 and RFX4_v4 are indicated in positive antibody staining. V, vector.

498 Cell lysates were loaded into two 10-lane gels and proteins were transferred to two polyvinylidene

499 difluoride (PVDF) membranes. Each membrane was cut into two pieces for incubation with

500 different sera and secondary antibodies. All four pieces of membranes were developed in one

501 cassette for the same exposure. Different contrast was applied to each piece after cropping with

502 Illustrator (Version 16.0.0, Adobe $^{\circledR}$ ). The full-length gel is included in the supplementary files

503 (Supplemental Fig. 5). It was performed once.

Fig. 2. RFX4 antigen specific CD4+ T cell receptor repertoire. (A) FACS dot plots of tetramer DQ0602-RFX4 staining, PBMCs were stimulated with $6.25 \mu \mathrm{M}$ RFX4 peptide in a 96-well plate $\left(1-2.5 \times 10^{6}\right.$ cells $\left./ \mathrm{ml}\right)$ for 10 days at $37^{\circ} \mathrm{C}, 5 \% \mathrm{CO}_{2} .20 \mathrm{IU} / \mathrm{ml}$ IL2 was supplemented from day 8 to day 10. Cultured cells were incubated with PE-labelled tetramer DQ0602-RFX4 peptide for 90 minutes at $37^{\circ} \mathrm{C}, 5 \% \mathrm{CO}_{2}$, followed by staining with BV421 anti-CD3, FITC anti-CD4 and AF700 anti-CD8 antibodies on ice. Live single CD3+ T cells with percentage of each quadrant population

511 are shown. EO-N, early onset patient; PP-N, post-Pandemrix ${ }^{\circledR}$ patient; PP-C, post-Pandemrix ${ }^{\circledR}$ 512 control; O-C, other controls. It was independently repeated at least once. (B) Paired TCR 513 enrichment. Tetramer DQ0602 positive CD4+CD8- T cells were single-cell sorted directly into 514 96-well plates, followed by 3 nested PCR reactions and TCR sequencing pipeline. TCR $\alpha \beta$ counts 515 in each subject-peptide reaction. Each slice represents a unique TCR $\alpha \beta$ clone. The number of 516 single cells for each unique clone is shown in the slices. Unnumbered slices represent a unique 517 clone that was observed only once. The total number of single cells (n) for each subject-peptide 518 reaction is displayed on $\mathrm{x}$-axis below subject. (C) Usage of V-gene segments in patient and control 519 paired TCR repertoire. Single cells obtained from all patients or controls respectively, using the 
same TRAV or TRBV gene, were grouped into one category. Each slice represents a unique TRAV

521 or TRBV gene (see adjacent legend) and the percentage of cells using it. TRAVs and TRBVs used

522 by less than $3 \%$ of cells are represented by slices without color and number. (D) TRBV and

523 corresponding TRAV/TRBV pairings to each RFX4-86/95/60 peptide. Each slice represents a

524 unique TRBV gene or TRAV/TRBV pairing. Slices show TRBV or TRAV genes used by more

525 than 5 single cells and the same TRBV gene is represented by the same color. In the TRAV/TRBV

526 pairing bar, the top digit describes the particular TRAV gene and the bottom number the total

527 number of single cells using each respective gene (and whether they were isolated from patients $\mathrm{P}$

528 or controls C). Diverse TRBV and TRAV/TRBV pairings expressed by fewer than 5 single cells

529 are represented by bars without color and annotation. TCR sequencing was performed once.

532 Fig. 3. Activation of TCR signaling by RFX4 antigens presented by DQ0602. Jurkat 76-NFATRE-

533 luc cells were transfected with TCR $\alpha \beta$ and then co-cultured with RM3-DQ0602 presented with 10

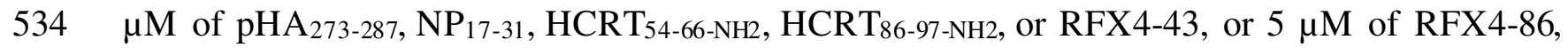

535 RFX4-95, or RFX4-60, or $0.2 \mu$ l DMSO for 8 hours. Luciferase activity was detected in a plate

$536(\mathrm{n}=3)$. Luminescence fold to RFX4-43 was shown. ***, $\mathrm{p}<0.001 ; * *, \mathrm{p}<0.01 ; *, \mathrm{p}<0.05$. It was

537 performed at least once. 


\section{References}

544 1. Schneider, L., and E. Mignot. 2017. Diagnosis and Management of Narcolepsy. Seminars $545 \quad$ in neurology 37: 446-460.

546 2. Peyron, C., J. Faraco, W. Rogers, B. Ripley, S. Overeem, Y. Charnay, S. Nevsimalova, 547 M. Aldrich, D. Reynolds, R. Albin, R. Li, M. Hungs, M. Pedrazzoli, M. Padigaru, M. 548 Kucherlapati, J. Fan, R. Maki, G. J. Lammers, C. Bouras, R. Kucherlapati, S. Nishino, 549 and E. Mignot. 2000. A mutation in a case of early onset narcolepsy and a generalized $550 \quad$ absence of hypocretin peptides in human narcoleptic brains. Nat Med 6: 991-997.

551 3. Thannickal, T. C., R. Y. Moore, R. Nienhuis, L. Ramanathan, S. Gulyani, M. Aldrich, M. 552 Cornford, and J. M. Siegel. 2000. Reduced Number of Hypocretin Neurons in Human $553 \quad$ Narcolepsy. Neuron 27: 469-474.

554 4. Faraco, J., L. Lin, B. R. Kornum, E. E. Kenny, G. Trynka, M. Einen, T. J. Rico, P. 555 Lichtner, Y. Dauvilliers, I. Arnulf, M. Lecendreux, S. Javidi, P. Geisler, G. Mayer, F. Pizza, F. Poli, G. Plazzi, S. Overeem, G. J. Lammers, D. Kemlink, K. Sonka, S. Nevsimalova, G. Rouleau, A. Desautels, J. Montplaisir, B. Frauscher, L. Ehrmann, B. Högl, P. Jennum, P. Bourgin, R. Peraita-Adrados, A. Iranzo, C. Bassetti, W.-M. Chen, P. Concannon, S. D. Thompson, V. Damotte, B. Fontaine, M. Breban, C. Gieger, N. Klopp, P. Deloukas, C. Wijmenga, J. Hallmayer, S. Onengut-Gumuscu, S. S. Rich, J.

563 5. Han, F., J. Faraco, X. S. Dong, H. M. Ollila, L. Lin, J. Li, P. An, S. Wang, K. W. Jiang, Z. C. Gao, L. Zhao, H. Yan, Y. N. Liu, Q. H. Li, X. Z. Zhang, Y. Hu, J. Y. Wang, Y. H. 
Mignot. 2013. Genome Wide Analysis of Narcolepsy in China Implicates Novel Immune Loci and Reveals Changes in Association Prior to Versus After the 2009 H1N1 Influenza Pandemic. PLOS Genetics 9: e1003880.

6. Juji, T., M. Satake, Y. Honda, and Y. Doi. 1984. HLA ANTIGENS IN JAPANESE PATIENTS WITH NARCOLEPSY - ALL THE PATIENTS WERE DR2 POSITIVE. Tissue Antigens 24: 316-319.

572 7. Mignot, E., A. Kimura, A. Lattermann, X. Lin, S. Yasunaga, G. Mueller-Eckhardt, C.

573 Rattazzi, L. Lin, C. Guilleminault, F. C. Grumet, G. Mayer, W. C. Dement, and P. Underhill. 1997. Extensive HLA class II studies in 58 non-DRB1*15 (DR2) narcoleptic patients with cataplexy. Tissue Antigens 49: 329-341.

8. Mignot, E., L. Lin, W. Rogers, Y. Honda, X. Qiu, X. Lin, M. Okun, H. Hohjoh, T. Miki, Three Ethnic Groups. American Journal of Human Genetics 68: 686-699.

9. Mignot, E., X. Lin, J. Arrigoni, C. Macaubas, F. Olive, J. Hallmayer, P. Underhill, C. Guilleminault, W. Dement, and F. C Grumet. 1995. DQB1*0602 and DQA1*0102 (DQ1) are better markers than DR2 for narcolepsy in Caucasian and Black Americans.

583 10. Ollila, Hanna M., J.-M. Ravel, F. Han, J. Faraco, L. Lin, X. Zheng, G. Plazzi, Y. Dauvilliers, F. Pizza, S.-C. Hong, P. Jennum, S. Knudsen, Birgitte R. Kornum, Xiao S. Dong, H. Yan, H. Hong, C. Coquillard, J. Mahlios, O. Jolanki, M. Einen, S. Lavault, B. Högl, B. Frauscher, C. Crowe, M. Partinen, Yu S. Huang, P. Bourgin, O. Vaarala, A. 
Mignot. 2015. HLA-DPB1 and HLA Class I Confer Risk of and Protection from Narcolepsy. American Journal of Human Genetics 96: 136-146.

11. Thomson, G. 1985. THE MODE OF INHERITANCE OF THE HLA-LINKED GENE PREDISPOSING TO NARCOLEPSY. Tissue Antigens 26: 201-203.

592 12. Hallmayer, J., J. Faraco, L. Lin, S. Hesselson, J. Winkelmann, M. Kawashima, G. Mayer, G. Plazzi, S. Nevsimalova, P. Bourgin, S. Hong, Y. Honda, M. Honda, B. Högl, W. T. Longstreth, J. Montplaisir, D. Kemlink, M. Einen, J. Chen, S. L. Musone, M. Akana, T. Miyagawa, J. Duan, A. Desautels, C. Erhardt, P. E. Hesla, F. Poli, B. Frauscher, J.-H. Jeong, S.-P. Lee, T. G. N. Ton, M. Kvale, L. Kolesar, M. Dobrovolná, G. T. Nepom, D. 708-711.

601 13. Ollila, H. M., E. Sharon, L. Lin, N. Sinnott-Armstrong, A. Ambati, R. P. Hillary, O. Jolanki, J. Faraco, M. Einen, G. Luo, J. Zhang, F. Han, H. Yan, X. S. Dong, J. Li, J. Zhang, S.-C. Hong, T. W. Kim, Y. Dauvilliers, L. Barateau, G. J. Lammers, R. Fronczek, G. Mayer, J. Santamaria, I. Arnulf, S. Knudsen, M. K. L. Bredahl, P. M. Thorsby, G. Plazzi, F. Pizza, M. Moresco, C. Crowe, S. K. Van den Eeden, M. Lecendreux, P. Bourgin, T. Kanbayashi, R. Peraita-Adrados, F. J. Martínez-Orozco, A. Benetó, J. Montplaisir, A. Desautels, Y.-S. Huang, P. Jennum, S. Nevsimalova, D. Kemlink, A. Iranzo, S. Overeem, A. Wierzbicka, P. Geisler, K. Sonka, M. Honda, B. Högl, A. Stefani, F. M. Coelho, V. Mantovani, E. Feketeova, M. Wadelius, N. Eriksson, H. Smedje, P. Hallberg, P. E. Hesla, D. Rye, Z. Pelin, L. Ferini-Strambi, C. L. Bassetti, J. Mathis, R. 
Khatami, A. Aran, S. Nampoothiri, T. Olsson, I. Kockum, M. Partinen, M. Perola, B. R. Kornum, S. Rueger, J. Winkelmann, T. Miyagawa, H. Toyoda, S. S. Khor, M. Shimada, K. Tokunaga, M. Rivas, J. K. Pritchard, N. Risch, Z. Kutalik, R. O’Hara, J. Hallmayer, C. J. Ye, and E. Mignot. 2018. Narcolepsy risk loci are enriched in immune cells and

616 14. Dauvilliers, Y., I. Arnulf, M. Lecendreux, C. Monaca Charley, P. Franco, X. Drouot, M.P. d'Ortho, S. Launois, S. Lignot, P. Bourgin, B. Nogues, M. Rey, S. Bayard, S. Scholz, S. Lavault, P. Tubert-Bitter, C. Saussier, and A. Pariente. 2013. Increased risk of narcolepsy in children and adults after pandemic H1N1 vaccination in France. Brain 136: 2486-2496.

621 15. Han, F., L. Lin, S. C. Warby, J. Faraco, J. Li, S. X. Dong, P. An, L. Zhao, L. H. Wang, Q. Neurology 70: 410-417.

625

16. Heier, M. S., K. M. Gautvik, E. Wannag, K. H. Bronder, E. Midtlyng, Y. Kamaleri, and J. Storsaeter. 2013. Incidence of narcolepsy in Norwegian children and adolescents after

17. Jacob, L., R. Leib, H. M. Ollila, M. Bonvalet, C. M. Adams, and E. Mignot. 2015. Comparison of Pandemrix and Arepanrix, two pH1N1 AS03-adjuvanted vaccines differentially associated with narcolepsy development. Brain, Behavior, and Immunity

632 18. Miller, E., N. Andrews, L. Stellitano, J. Stowe, A. M. Winstone, J. Shneerson, and C. Verity. 2013. Risk of narcolepsy in children and young people receiving AS03 
adjuvanted pandemic A/H1N1 2009 influenza vaccine: retrospective analysis. $B M J$ : British Medical Journal 346.

636 19. Nohynek, H., J. Jokinen, M. Partinen, O. Vaarala, T. Kirjavainen, J. Sundman, S.-L. Himanen, C. Hublin, I. Julkunen, P. Olsén, O. Saarenpää-Heikkilä, and T. Kilpi. 2012. AS03 Adjuvanted AH1N1 Vaccine Associated with an Abrupt Increase in the Incidence of Childhood Narcolepsy in Finland. PLOS ONE 7: e33536.

20. Partinen, M., O. Saarenpää-Heikkilä, I. Ilveskoski, C. Hublin, M. Linna, P. Olsén, P. Nokelainen, R. Alén, T. Wallden, M. Espo, H. Rusanen, J. Olme, H. Sätilä, H. Arikka, P. Kaipainen, I. Julkunen, and T. Kirjavainen. 2012. Increased Incidence and Clinical Picture of Childhood Narcolepsy following the 2009 H1N1 Pandemic Vaccination

21. Pizza, F., H. Peltola, T. Sarkanen, K. K. Moghadam, G. Plazzi, and M. Partinen. 2014. Childhood narcolepsy with cataplexy: comparison between post-H1N1 vaccination and sporadic cases. Sleep Medicine 15: 262-265.

648 22. Winstone, A. M., L. Stellitano, C. Verity, N. Andrews, E. Miller, J. Stowe, and J. Shneerson. 2014. Clinical features of narcolepsy in children vaccinated with AS03 adjuvanted pandemic A/H1N1 2009 influenza vaccine in England. Developmental

652 23. Dauvilliers, Y., J. Montplaisir, V. Cochen, A. Desautels, M. Einen, L. Lin, M.

653 Kawashima, S. Bayard, C. Monaca, M. Tiberge, D. Filipini, A. Tripathy, B. H. Nguyen, 654 S. Kotagal, and E. Mignot. 2010. Post-H1N1 narcolepsy-cataplexy. Sleep 33: 1428-1430.

655 24. Bardage, C., I. Persson, A. Ortqvist, U. Bergman, J. F. Ludvigsson, and F. Granath. 2011. Neurological and autoimmune disorders after vaccination against pandemic influenza A 
(H1N1) with a monovalent adjuvanted vaccine: population based cohort study in Stockholm, Sweden. BMJ (Clinical research ed.) 343: d5956.

659 25. Montplaisir, J., G. Poirer, O. Lapierre, and M. J. 1989. Streptococcal antibodies in 660 narcolepsy and idiopathic hypersomnia. Sleep Res. 18: 271.

661 26. Kim, T. W., D. W. Kang, S.-Y. Kim, J. H. Han, S. P. Lee, and S. C. Hong. 2012.

662 Comparison of Anti-Streptococcal Antibodies in Patients with Narcolepsy and Control 663 Group. Sleep Med Res 3: 15-19.

664 27. Aran, A., L. Lin, S. Nevsimalova, G. Plazzi, S. C. Hong, K. Weiner, J. Zeitzer, and E. Mignot. 2009. Elevated Anti-Streptococcal Antibodies in Patients with Recent Narcolepsy Onset. Sleep 32: 979-983.

667 28. Mueller-Eckhardt, G., K. Meier-Ewart, and H. G. Schiefer. Is there an infectious origin of

29. Koepsell, T. D., W. T. Longstreth, and T. G. N. Ton. 2010. Medical exposures in youth and the frequency of narcolepsy with cataplexy: a population-based case-control study in genetically predisposed people. Journal of Sleep Research 19: 80-86.

30. Snider, L. A., and S. E. Swedo. 2004. PANDAS: current status and directions for research. Mol Psychiatry 9: 900-907.

674 31. Cvetkovic-Lopes, V., L. Bayer, S. Dorsaz, S. Maret, S. Pradervand, Y. Dauvilliers, M. Lecendreux, G. J. Lammers, C. E. Donjacour, R. A. Du Pasquier, C. Pfister, B. Petit, H. Hor, M. Mühlethaler, and M. Tafti. 2010. Elevated Tribbles homolog 2-specific antibody

678 32. Mignot, E. J. 2014. History of narcolepsy at Stanford University. Immunologic research 679 58: 315-339. 
680 33. Wallenius, M., A. Lind, O. Akel, E. Karlsson, M. Svensson, E. Arvid sson, A. Ramelius,

681 C. Törn, L. Palm, Å. Lernmark, and H. Elding Larsson. 2019. Autoantibodies in

682 Pandemrix(®)-induced narcolepsy: Nine candidate autoantigens fail the conformational 683 autoantibody test. Autoimmunity 52: 185-191.

684 34. Dalal, J., J. H. Roh, S. E. Maloney, A. Akuffo, S. Shah, H. Yuan, B. Wamsley, W. B.

685 Jones, C. de Guzman Strong, P. A. Gray, D. M. Holtzman, N. Heintz, and J. D.

686 Dougherty. 2013. Translational profiling of hypocretin neurons identifies candidate

687 molecules for sleep regulation. Genes Dev 27: 565-578.

688 35. Tanaka, S., Y. Honda, Y. Inoue, and M. Honda. 2006. Detection of autoantibodies

689 against hypocretin, hcrtrl, and hortr2 in narcolepsy: anti-Hcrt system antibody in

$690 \quad$ narcolepsy. Sleep 29: 633-638.

691 36. Giannoccaro, M. P., P. Waters, F. Pizza, R. Liguori, G. Plazzi, and A. Vincent. 2017.

692 Antibodies Against Hypocretin Receptor 2 Are Rare in Narcolepsy. Sleep 40: zsw056-

$693 \quad$ zsw056.

694 37. Luo, G., L. Lin, L. Jacob, M. Bonvalet, A. Ambati, G. Plazzi, F. Pizza, R. Leib, C. M. Adams, M. Partinen, and E. J.-M. Mignot. 2017. Absence of anti-hypocretin receptor 2 autoantibodies in post pandemrix narcolepsy cases. PLOS ONE 12: e0187305.

697 38. Ahmed, S. S., W. Volkmuth, J. Duca, L. Corti, M. Pallaoro, A. Pezzicoli, A. Karle, F. Rigat, R. Rappuoli, V. Narasimhan, I. Julkunen, A. Vuorela, O. Vaarala, H. Nohynek, F.

699 L. Pasini, E. Montomoli, C. Trombetta, C. M. Adams, J. Rothbard, and L. Steinman. 700 2015. Antibodies to influenza nucleoprotein cross-react with human hypocretin receptor 701 2. Science Translational Medicine 7: 294ra105. 
702 39. Aran, A., K. Weiner, L. Lin, L. A. Finn, M. A. Greco, P. Peppard, T. Young, Y. Ofran, 703 and E. Mignot. 2010. Post-streptococcal auto-antibodies inhibit protein disulfide $704 \quad$ isomerase and are associated with insulin resistance. PLoS One 5: e12875.

705 40. Deloumeau, A., S. Bayard, Q. Coquerel, P. Déchelotte, C. Bole-Feysot, B. Carlander, V. 706 Cochen De Cock, S. O. Fetissov, and Y. Dauvilliers. 2010. Increased immune complexes 707 of hypocretin autoantibodies in narcolepsy. PLoS One 5: e13320.

708 41. Mahoney, C. E., A. Cogswell, I. J. Koralnik, and T. E. Scammell. 2019. The 709

42. Amatoury, M., V. Merheb, J. Langer, X. M. Wang, R. C. Dale, and F. Brilot. 2013. High-

714 43. Van Elssen, C. H. M. J., H. Clausen, W. T. V. Germeraad, E. P. Bennet, P. P. Menheere,

717 44. Latorre, D., U. Kallweit, E. Armentani, M. Foglierini, F. Mele, A. Cassotta, S. Jovic, D.

721 45. Pedersen, N. W., A. Holm, N. P. Kristensen, A. M. Bjerregaard, A. K. Bentzen, A. M. and B. R. Kornum. 2019. CD8(+) T cells from patients with narcolepsy and healthy controls recognize hypocretin neuron-specific antigens. Nat Commun 10: 837. 
725 46. Luo, G., A. Ambati, L. Lin, M. Bonvalet, M. Partinen, X. Ji, H. T. Maecker, and E. J.-M. Mignot. 2018. Autoimmunity to hypocretin and molecular mimicry to flu in type 1 narcolepsy. Proceedings of the National Academy of Sciences 115: E12323-E12332.

728 47. Pedersen, N. W., A. Holm, N. P. Kristensen, A.-M. Bjerregaard, A. K. Bentzen, A. M. Marquard, T. Tamhane, K. S. Burgdorf, H. Ullum, P. Jennum, S. Knudsen, S. R. Hadrup, and B. R. Kornum. 2019. CD8+ T cells from patients with narcolepsy and healthy controls recognize hypocretin neuron-specific antigens. Nature Communications 10: 837.

732 48. Davis, M. M., and P. J. Bjorkman. 1988. T-cell antigen receptor genes and T-cell recognition. Nature 334: 395-402.

734 49. Klenerman, P., V. Cerundolo, and P. R. Dunbar. 2002. Tracking T cells with tetramers: new tales from new tools. Nat Rev Immunol 2: 263-272.

736 50. Dash, P., A. J. Fiore-Gartland, T. Hertz, G. C. Wang, S. Sharma, A. Souquette, J. C. 737 Crawford, E. B. Clemens, T. H. O. Nguyen, K. Kedzierska, N. L. La Gruta, P. Bradley,

740 51. Glanville, J., H. Huang, A. Nau, O. Hatton, L. E. Wagar, F. Rubelt, X. Ji, A. Han, S. M. and P. G. Thomas. 2017. Quantifiable predictive features define epitope-specific T cell receptor repertoires. Nature 547: 89-93.

744 52. Jiang, W., J. R. Birtley, S.-C. Hung, W. Wang, S.-H. Chiou, C. Macaubas, B. Kornum, L. Ayyangar, M. M. Davis, L. J. Stern, and E. D. Mellins. 2019. In vivo clonal expansion 
and phenotypes of hypocretin-specific CD4+ T cells in narcolepsy patients and controls. In Nature communications. 5247.

749 53. Doyle, J. P., J. D. Dougherty, M. Heiman, E. F. Schmidt, T. R. Stevens, G. Ma, S. Bupp,

753 54. Dougherty, J. D., E. F. Schmidt, M. Nakajima, and N. Heintz. 2010. Analytical approaches to RNA profiling data for the identification of genes enriched in specific cells. Nucleic Acids Research 38: 4218-4230.

55. Emery, P., B. Durand, B. Mach, and W. Reith. 1996. RFX proteins, a novel family of DNA binding proteins conserved in the eukaryotic kingdom. Nucleic Acids Research 24: 803-807.

56. Iwama, A., J. Pan, P. Zhang, W. Reith, B. Mach, D. G. Tenen, and Z. Sun. 1999. Dimeric RFX Proteins Contribute to the Activity and Lineage Specificity of the Interleukin-5 Receptor $\alpha$ Promoter through Activation and Repression Domains. Molecular and Cellular Biology 19: 3940-3950.

57. Gajiwala, K. S., H. Chen, F. Cornille, B. P. Roques, W. Reith, B. Mach, and S. K. Burley. 2000. Structure of the winged-helix protein hRFX1 reveals a new mode of DNA binding. Nature 403: 916-921.

58. Reith, W., C. Ucla, E. Barras, A. Gaud, B. Durand, C. Herrero-Sanchez, M. Kobr, and B. Mach. 1994. RFX1, a transactivator of hepatitis B virus enhancer I, belongs to a novel family of homodimeric and heterodimeric DNA-binding proteins. Molecular and Cellular Biology 14: 1230-1244. 
770 59. Reith, W., E. Barras, S. Satola, M. Kobr, D. Reinhart, C. H. Sanchez, and B. Mach. 1989. Cloning of the major histocompatibility complex class II promoter binding protein affected in a hereditary defect in class II gene regulation. Proceedings of the National Academy of Sciences of the United States of America 86: 4200-4204.

774 60. Reith, W., C. Herrero-Sanchez, M. Kobr, P. Silacci, C. Berte, E. Barras, S. Fey, and B. Mach. 1990. MHC class II regulatory factor RFX has a novel DNA-binding domain and a

61. Morotomi-Yano, K., K.-i. Yano, H. Saito, Z. Sun, A. Iwama, and Y. Miki. 2002. Human Regulatory Factor X 4 (RFX4) Is a Testis-specific Dimeric DNA-binding Protein That Cooperates with Other Human RFX Members. Journal of Biological Chemistry 277: 836842.

781 62. Bonnafe, E., M. Touka, A. AitLounis, D. Baas, E. Barras, C. Ucla, A. Moreau, F. Transcription Factor RFX3 Directs Nodal Cilium Development and Left-Right Asymmetry Specification. Molecular and Cellular Biology 24: 4417-4427.

63. Farrokhi, S., M. Shabani, Z. Aryan, S. Zoghi, A. Krolo, K. Boztug, and N. Rezaei. 2018. MHC class II deficiency: Report of a novel mutation and special review. Allergologia et Immunopathologia 46: 263-275.

64. Zhang, D., D. C. Zeldin, and P. J. Blackshear. 2007. Regulatory Factor X4 Variant 3: A Transcription Factor Involved in Brain Development and Disease. Journal of neuroscience research 85: 3515-3522.

791 65. Matsushita, H., A. Uenaka, T. Ono, K. Hasegawa, S. Sato, F. Koizumi, K. Nakagawa, M. 792 Toda, T. Shingo, T. Ichikawa, Y. Noguchi, T. Tamiya, T. Furuta, T. Kawase, I. Date, and 
E. Nakayama. 2005. Identification of glioma-specific RFX4-E and -F isoforms and humoral immune response in patients. Cancer Science 96: 801-809.

795 66. Zhang, D., D. J. Stumpo, J. P. Graves, L. M. DeGraff, S. F. Grissom, J. B. Collins, L. Li, D. C. Zeldin, and P. J. Blackshear. 2006. Identification of potential target genes for RFX4_v3, a transcription factor critical for brain development. Journal of

67. Ashique, A. M., Y. Choe, M. Karlen, S. R. May, K. Phamluong, M. J. Solloway, J. Ericson, and A. S. Peterson. 2009. The Rfx4 Transcription Factor Modulates Shh Signaling by Regional Control of Ciliogenesis. Science Signaling 2: ra70-ra70.

802 68. Seubert, J., B. Yang, J. A. Bradbury, J. Graves, L. M. Degraff, S. Gabel, R. Gooch, J. Foley, J. Newman, L. Mao, H. A. Rockman, B. D. Hammock, E. Murphy, and D. C. Zeldin. 2004. Enhanced Postischemic Functional Recovery in CYP2J2 Transgenic Hearts Involves Mitochondrial ATP-Sensitive $\mathrm{K}<$ sup $>+</$ sup $>$ Channels and p42/p44 MAPK Pathway. Circulation Research 95: 506-514.

807 69. Blackshear, P. J., J. P. Graves, D. J. Stumpo, I. Cobos, J. L. R. Rubenstein, and D. C. Zeldin. 2003. Graded phenotypic response to partial and complete deficiency of a brainspecific transcript variant of the winged helix transcription factor RFX4. Development 130: 4539-4552.

811 70. Herzog, E. D., J. S. Takahashi, and G. D. Block. 1998. Clock controls circadian period in 812 isolated suprachiasmatic nucleus neurons. Nat Neurosci 1: 708-713.

813 71. van den Pol, A. N. 1980. The hypothalamic suprachiasmatic nucleus of rat: Intrinsic 814 anatomy. The Journal of Comparative Neurology 191: 661-702. 
815 72. Ko, C. H., and J. S. Takahashi. 2006. Molecular components of the mammalian circadian 816 clock. Human Molecular Genetics 15: R271-R277.

817 73. Araki, R., H. Takahashi, R. Fukumura, F. Sun, N. Umeda, M. Sujino, S.-I. T. Inouye, T. 818 Saito, and M. Abe. 2004. Restricted Expression and Photic Induction of a Novel Mouse 819 Regulatory Factor X4 Transcript in the Suprachiasmatic Nucleus. Journal of Biological $820 \quad$ Chemistry 279: 10237-10242.

821 74. Glaser, B., G. Kirov, N. J. Bray, E. Green, M. C. O'Donovan, N. Craddock, and M. J. 822 Owen. 2005. Identification of a potential Bipolar risk haplotype in the gene encoding the 823 winged-helix transcription factor RFX4. Mol Psychiatry 10: 920-927.

824 75. Curtis, D., G. Kalsi, J. Brynjolfsson, M. McInnis, J. O'Neill, C. Smyth, E. Moloney, P. 825 Murphy, A. McQuillin, H. Petursson, and H. Gurling. 2003. Genome scan of pedigrees 826 multiply affected with bipolar disorder provides further support for the presence of a 827 susceptibility locus on chromosome 12q23-q24, and suggests the presence of additional $828 \quad$ loci on 1p and 1q. Psychiatric Genetics 13: 77-84.

829 76. Wehr, T. A., D. Sack, N. Rosenthal, W. Duncan, and J. C. Gillin. 1983. Circadian rhythm 830 disturbances in manic-depressive illness. Federation proceedings 42: 2809-2814.

831 77. Murray, G., and A. Harvey. 2010. Circadian rhythms and sleep in bipolar disorder. 832 Bipolar Disorders 12: 459-472.

833 78. Schmidt, H.-H., Y. Ge, F. J. Hartmann, H. Conrad, F. Klug, S. Nittel, H. Bernhard, C.

834 Domschke, F. Schuetz, C. Sohn, and P. Beckhove. 2013. HLA Class II tetramers reveal 835 tissue-specific regulatory $\mathrm{T}$ cells that suppress T-cell responses in breast carcinoma 836 patients. Oncoimmunology 2: e24962. 
837 79. Kwok, W. W., A. W. Liu, E. J. Novak, J. A. Gebe, R. A. Ettinger, G. T. Nepom, S. N. Reymond, and D. M. Koelle. 2000. HLA-DQ Tetramers Identify Epitope-Specific T Cells in Peripheral Blood of Herpes Simplex Virus Type 2-Infected Individuals: Direct Detection of Immunodominant Antigen-Responsive Cells. The Journal of Immunology 164: 4244-4249.

842 80. McKinney, D. M., S. Southwood, D. Hinz, C. Oseroff, C. S. L. Arlehamn, V. Schulten,

847 81. Mahoney, C. E., A. Cogswell, I. J. Koralnik, and T. E. Scammell. 2019. The neurobiological basis of narcolepsy. Nature Reviews Neuroscience 20: 83-93. 
Figures
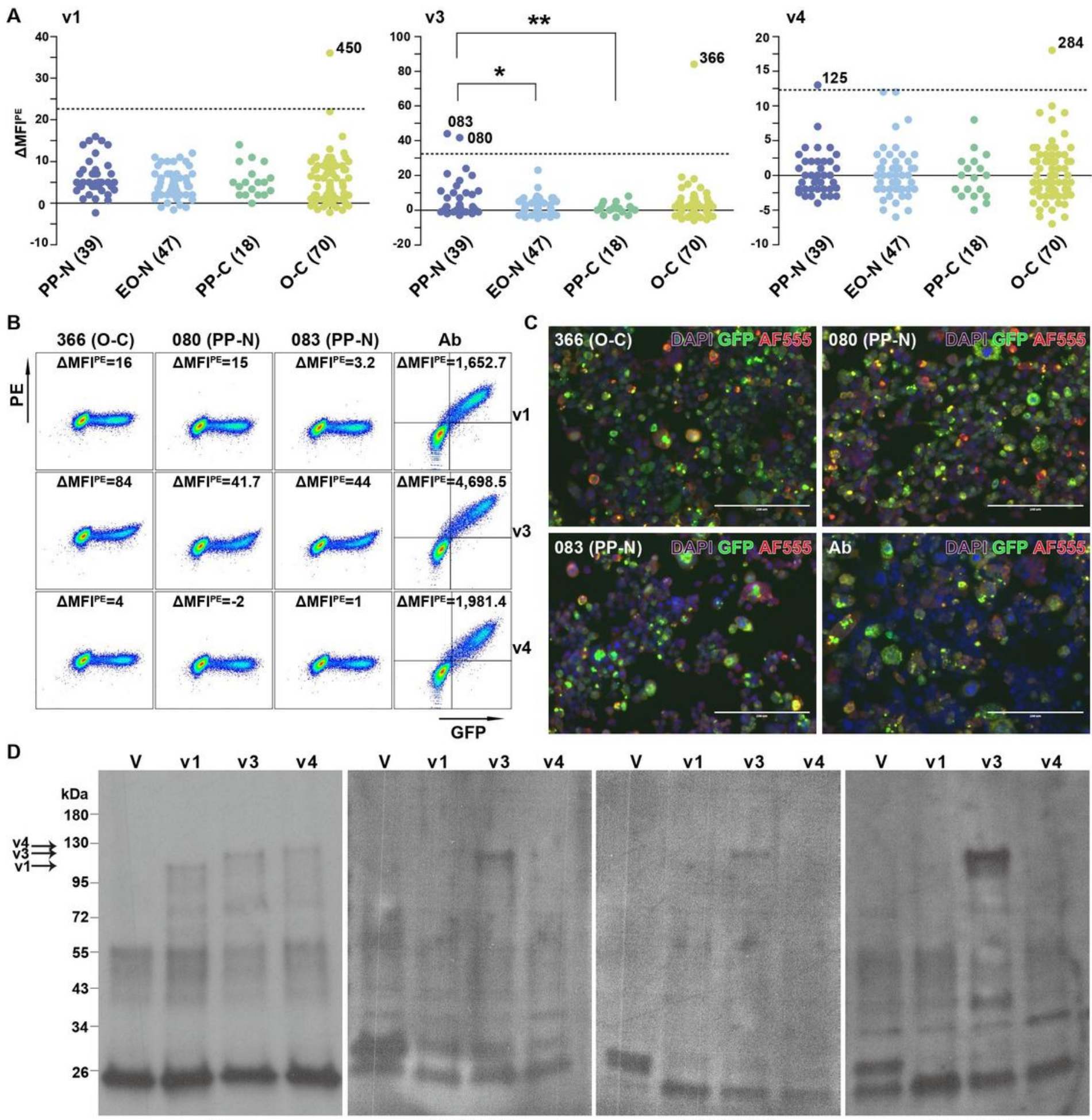

$\mathrm{Ab}$

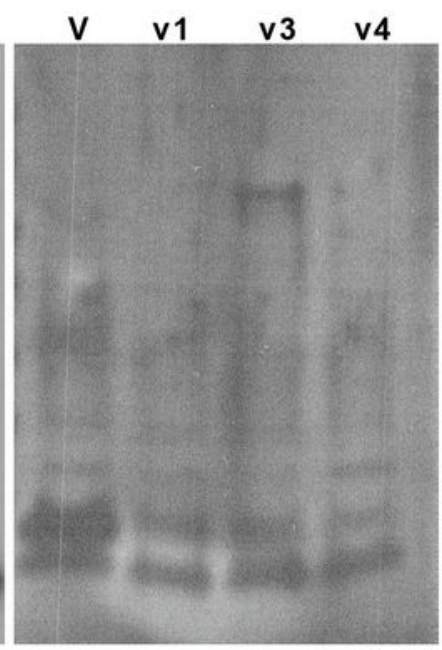

$366(\mathrm{O}-\mathrm{C})$

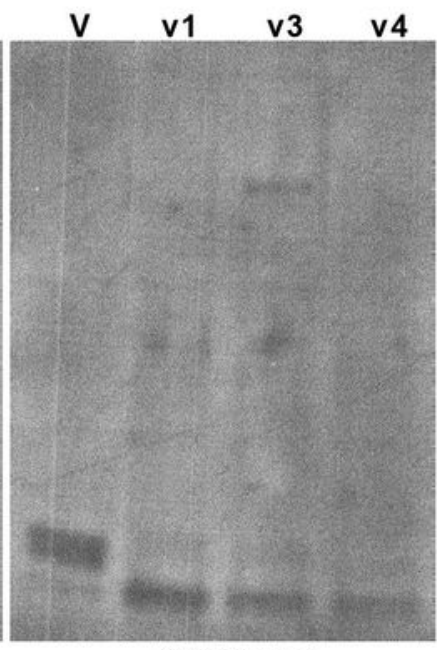

080 (PP-N)

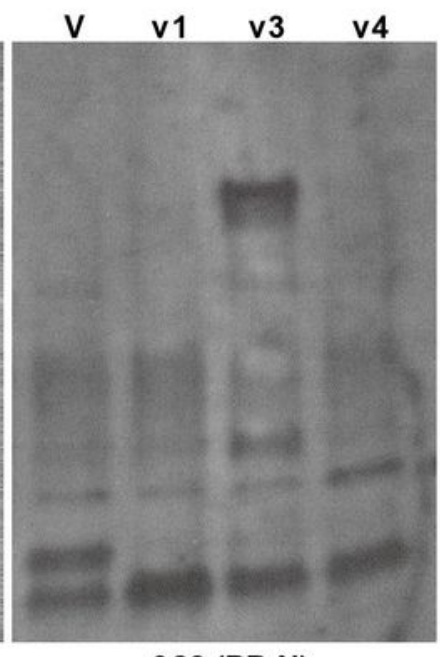

083 (PP-N)

Figure 1

Anti-RFX4 autoantibody detection. (A) Sera were screened using HEK293T cells expressing GFP tagged RFX4 variants and PE-conjugated anti-human $\lg \lambda / K$ antibody. Analysis was performed between groups of post-Pandemrix ${ }^{\circledR}$ T1N (PP-N) patients, post-Pandemrix ${ }^{\circledR}$ controls (PP-C), recent early onset T1N (EO-N) 
patients, and other controls (O-C) for RFX4_v1, RFX4_v3, and RFX4_v4. Each dot corresponds to one subject. $\triangle$ MFIPE $=$ (MFIPE of HEK293TGFP+) $-($ MFIPE of HEK293TGFP-). Cut-off value of $\triangle$ MFIPE, which is denoted by dotted line, was determined as the mean of $\triangle M F I P E+3 \times$ standard deviation (SD) of control samples. Subject IDs above cut-off value and statistical significance are shown. ${ }^{*}, \mathrm{P}<0.05$; $* \star, P<$ 0.01. It was independently repeated once. (B) FACS dot plots of three subjects in anti-RFX4 autoantibody detection. HEK293T cells expressing RFX4_v1, v3 and v4-GFP were incubated with human serum (1:20) or positive rabbit anti-RFX4 antibody, followed by PE anti-human $\lg \lambda / \kappa$ antibody (1:100) or PE anti-rabbit IgG antibody (1:100), respectively. Representative dot plots of 3 subjects and positive antibody (1:500) with $\%$ of each quadrant population in live single cells are shown. Ab, antibody. It was independently repeated once. (C) Anti-RFX4_v3 autoantibody detection using cell-based immunostaining and observation under microscope. HEK293T cells expressing GFP-tagged RFX4_v1, v3, and v4 were stained with human serum (1:20) or rabbit anti-RFX4 antibody (Ab) (1:500), followed by AF555-conjugated antihuman IgG antibody (1:500) or AF555-conjugated anti-rabbit IgG antibody (1:500), respectively. 3 subjects with $\triangle M F I P E$ above cut-off value of RFX4_v3 were tested. Bar=200 $\mu \mathrm{m}$. It was performed once. (D) Anti-RFX4 autoantibody detection using western blotting. HEK293T cells expressing GFP-tagged RFX4_v1, v3, v4 and vector were lysed and anti-tGFP-conjugated agarose beads were incubated with supernatant for Co-IP. Positive antibody and three subjects with $\triangle$ MFIPE above cut-off value were tested. RFX4_v1, RFX4_V3 and RFX4_v4 are indicated in positive antibody staining. V, vector. Cell lysates were loaded into two 10-lane gels and proteins were transferred to two polyvinylidene difluoride (PVDF) membranes. Each membrane was cut into two pieces for incubation with different sera and secondary antibodies. All four pieces of membranes were developed in one cassette for the same exposure. Different contrast was applied to each piece after cropping with Illustrator (Version 16.0.0, Adobe ${ }^{\circledR}$ ). The full-length gel is included in the supplementary files (Supplemental Fig. 5). It was performed once. 

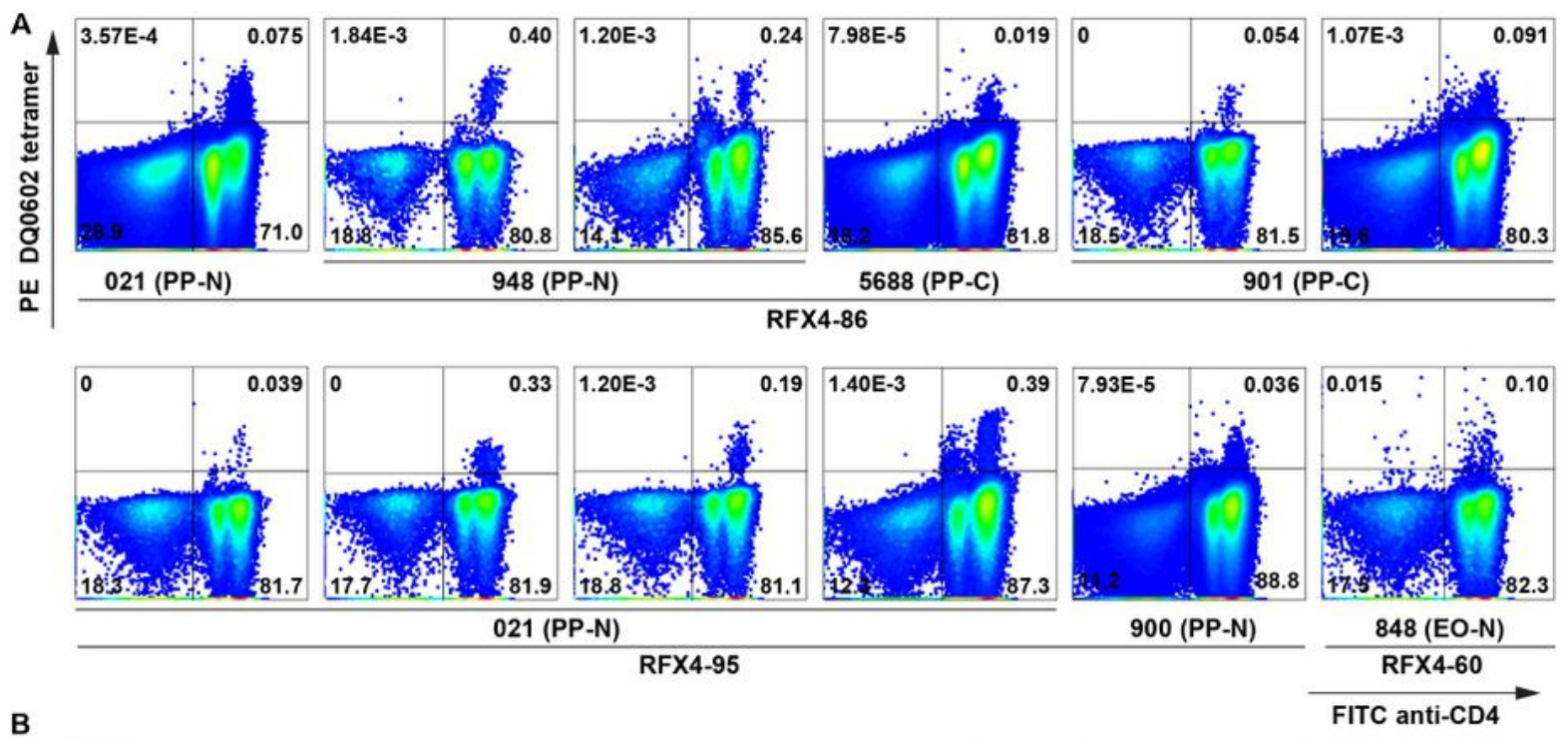

B

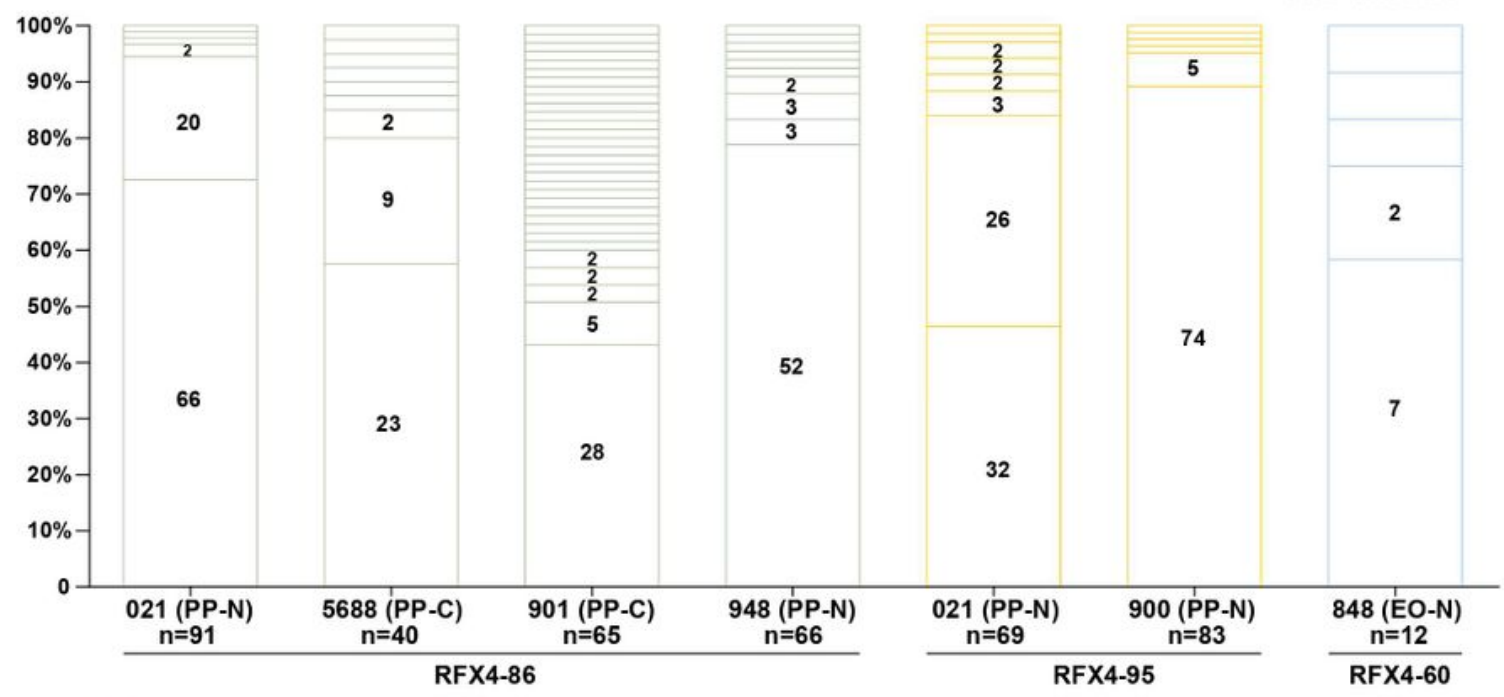

C
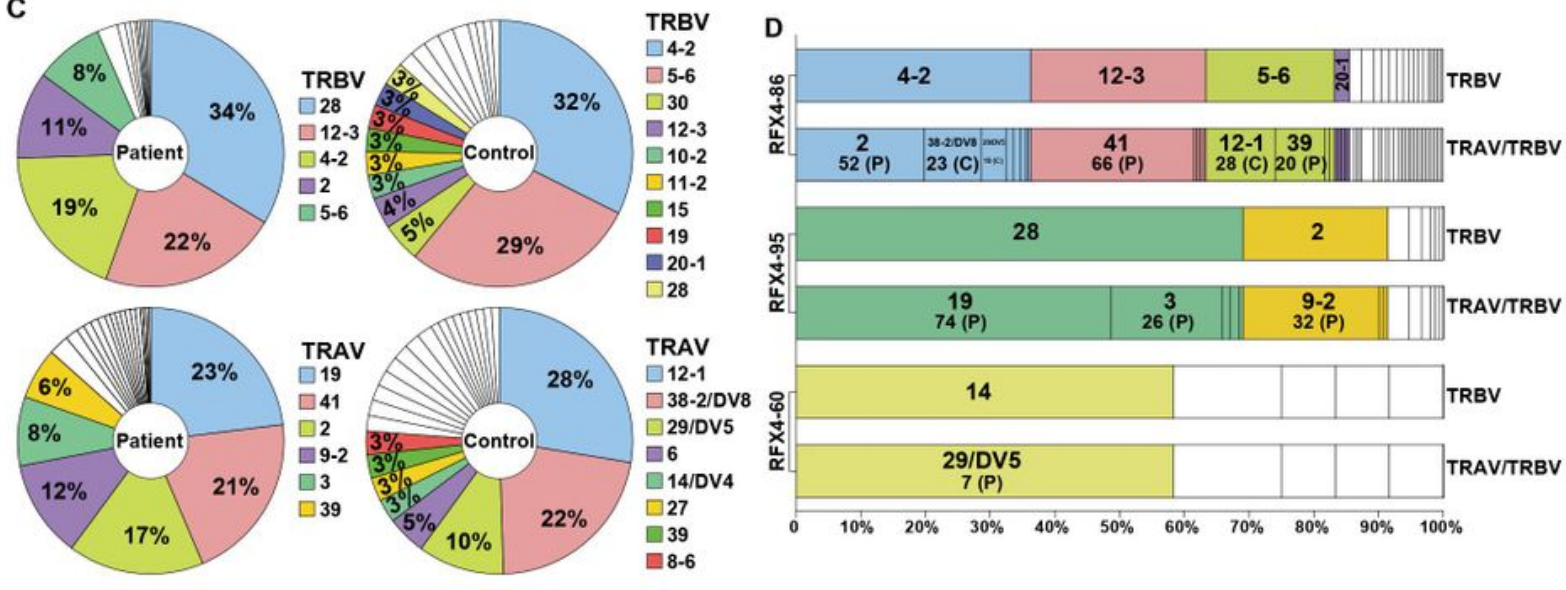

\section{Figure 2}

RFX4 antigen specific CD4+ T cell receptor repertoire. (A) FACS dot plots of tetramer DQ0602-RFX4 staining, PBMCs were stimulated with $6.25 \mu \mathrm{M}$ RFX4 peptide in a 96-well plate $(1-2.5 \times 106 \mathrm{cell} / \mathrm{ml})$ for 10 days at $37^{\circ} \mathrm{C}, 5 \% \mathrm{CO} 2.20 \mathrm{IU} / \mathrm{ml} \mathrm{IL2}$ was supplemented from day 8 to day 10 . Cultured cells were incubated with PE-labelled tetramer DQ0602-RFX4 peptide for 90 minutes at $37^{\circ} \mathrm{C}, 5 \% \mathrm{CO}$, followed by staining with BV421 anti-CD3, FITC anti-CD4 and AF700 anti-CD8 antibodies on ice. Live single CD3+ T 
cells with percentage of each quadrant population are shown. EO-N, early onset patient; PP-N, postPandemrix ${ }^{\circledR}$ patient; PP-C, post-Pandemrix ${ }^{\circledR}$ control; O-C, other controls. It was independently repeated at least once. (B) Paired TCR enrichment. Tetramer DQ0602 positive CD4+CD8- T cells were single-cell sorted directly into 96-well plates, followed by 3 nested PCR reactions and TCR sequencing pipeline. TCRa $\beta$ counts in each subject-peptide reaction. Each slice represents a unique TCRa $\beta$ clone. The number of single cells for each unique clone is shown in the slices. Unnumbered slices represent a unique clone that was observed only once. The total number of single cells $(n)$ for each subject-peptide reaction is displayed on x-axis below subject. (C) Usage of V-gene segments in patient and control paired TCR repertoire. Single cells obtained from all patients or controls respectively, using the same TRAV or TRBV gene, were grouped into one category. Each slice represents a unique TRAV or TRBV gene (see adjacent legend) and the percentage of cells using it. TRAVs and TRBVs used by less than $3 \%$ of cells are represented by slices without color and number. (D) TRBV and corresponding TRAV/TRBV pairings to each RFX4-86/95/60 peptide. Each slice represents a unique TRBV gene or TRAV/TRBV pairing. Slices show TRBV or TRAV genes used by more than 5 single cells and the same TRBV gene is represented by the same color. In the TRAV/TRBV pairing bar, the top digit describes the particular TRAV gene and the bottom number the total number of single cells using each respective gene (and whether they were isolated from patients $P$ or controls $C$ ). Diverse TRBV and TRAV/TRBV pairings expressed by fewer than 5 single cells are represented by bars without color and annotation. TCR sequencing was performed once. 
A

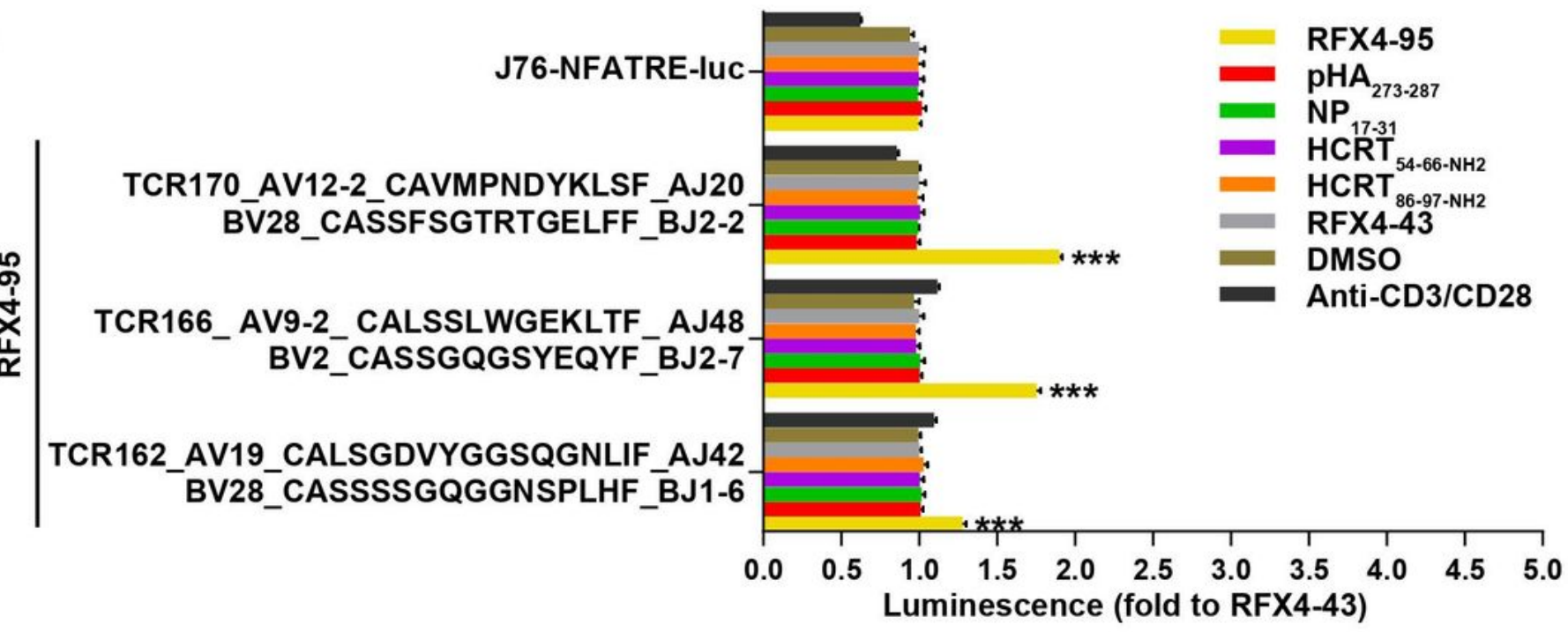

B

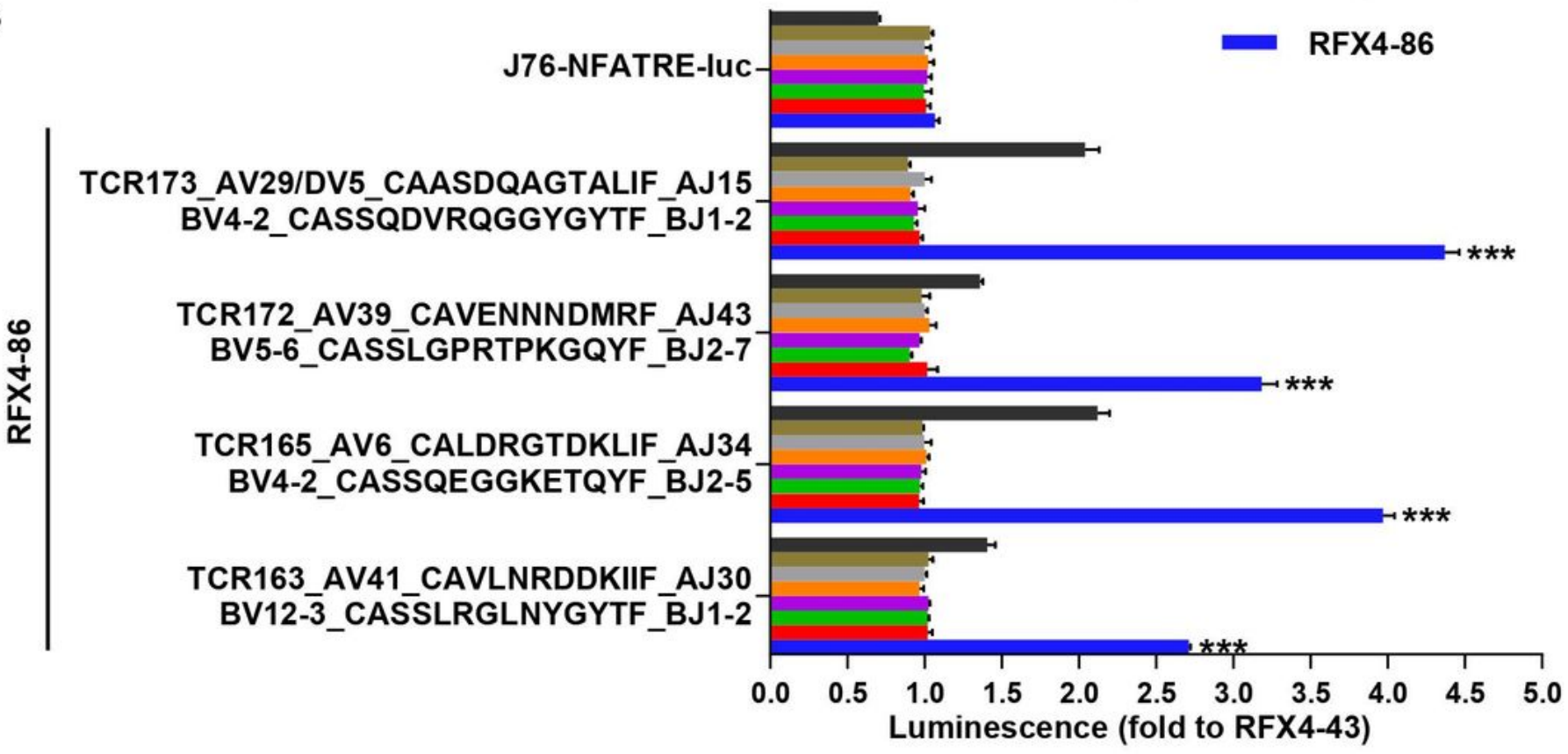

C

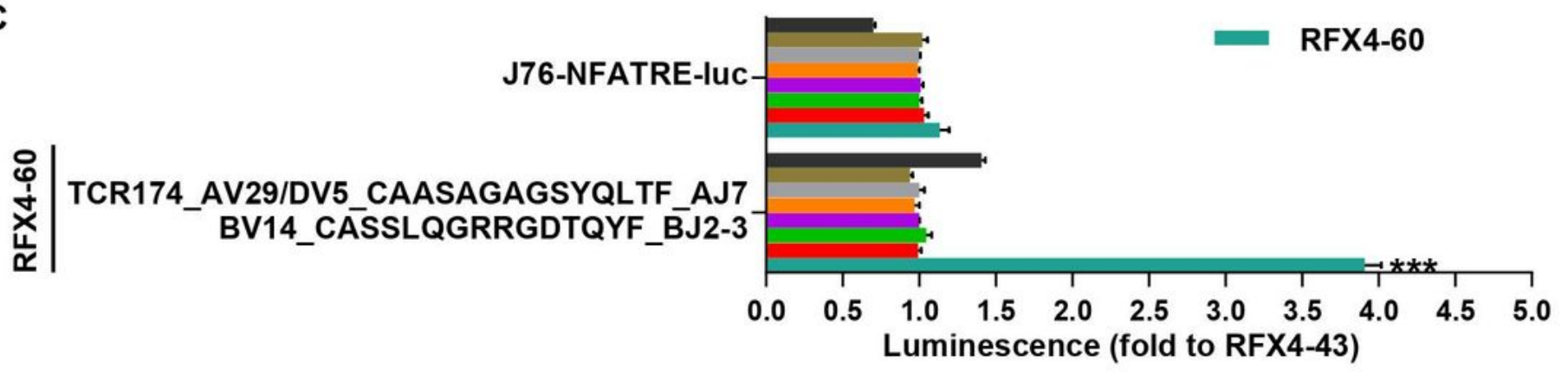

Figure 3

Activation of TCR signaling by RFX4 antigens presented by DQ0602. Jurkat 76-NFATRE-luc cells were transfected with TCRaß and then co-cultured with RM3-DQ0602 presented with 10 $\mu \mathrm{M}$ of pHA273-287, NP17-31, HCRT54-66-NH2, HCRT86-97-NH2, or RFX4-43, or 5 нM of RFX4-86, RFX4-95, or RFX4-60, or 0.2 $\mu \mathrm{l}$ DMSO for 8 hours. Luciferase activity was detected in a plate $(n=3)$. Luminescence fold to RFX4-43 was shown. ${ }^{* *}, p<0.001 ; * *, p<0.01 ;{ }^{*}, p<0.05$. It was performed at least once. 


\section{Supplementary Files}

This is a list of supplementary files associated with this preprint. Click to download.

- Tablel.docx

- Tablell.docx

- Dataset1.xls

- Dataset2.xls

- Dataset3.xls

- Dataset4.xIs

- supplementalfiguresandlgends.pdf 